\title{
A nitrogen budget for the Strait of Georgia, British Columbia, with emphasis on particulate nitrogen and dissolved inorganic nitrogen
}

\author{
J. N. Sutton ${ }^{1,2}$, S. C. Johannessen ${ }^{1}$, and R. W. Macdonald ${ }^{1}$ \\ ${ }^{1}$ Institute of Ocean Sciences, Fisheries and Oceans Canada, 9860 West Saanich Road, P.O. Box 6000, Sidney, British \\ Columbia, V8L 4B2, Canada \\ ${ }^{2}$ Department of Earth and Planetary Science, University of California, Berkeley, California, 94720, USA
}

Correspondence to: J. N. Sutton (jill.n.sutton@gmail.com)

Received: 6 March 2013 - Published in Biogeosciences Discuss.: 23 April 2013

Revised: 29 September 2013 - Accepted: 10 October 2013 - Published: 12 November 2013

\begin{abstract}
Balanced budgets for dissolved inorganic N (DIN) and particulate $\mathrm{N}(\mathrm{PN})$ were constructed for the Strait of Georgia (SoG), a semi-enclosed coastal sea off the west coast of British Columbia, Canada. The dominant control on the $\mathrm{N}$ budget is the advection of DIN into and out of the SoG via Haro Strait. The annual influx of DIN by advection from the Pacific Ocean is $29990( \pm 19500) \mathrm{Mmol} \mathrm{yr}^{-1}$. The DIN flux advected out of the SoG is $24300( \pm 15500) \mathrm{Mmol} \mathrm{yr}^{-1}$. Most of the DIN that enters the SoG $\left(\sim 23400 \mathrm{Mmol} \mathrm{yr}^{-1}\right)$ is converted to particulate $\mathrm{N}(\mathrm{PN})$ in situ by primary production. However, most of the $\mathrm{PN}$ produced by primary production is remineralized $\left(\sim 22000 \mathrm{Mmol} \mathrm{yr}^{-1}\right)$ back into DIN within the top $50 \mathrm{~m}$. The PN budget for the SoG was further constrained by nitrogen isotope composition $\left(\delta^{15} \mathrm{~N}\right)$ that indicated regional differences in the source of PN. The southern strait receives a much higher proportion of terrigenous $\mathrm{PN}$, relative to marine $\mathrm{PN}$, than does the northern strait. The difference is due to the influence of the Fraser River, which discharges $1950 \mathrm{Mmol} \mathrm{yr}^{-1}$ of PN and $1660 \mathrm{Mmol} \mathrm{yr}^{-1}$ of DIN into the southern strait. The overall anthropogenic contribution of PN and DIN to the SoG is minimal relative to natural sources (> $30000 \mathrm{Mmol} \mathrm{yr}^{-1}$ ). It is unlikely that the strait will be affected by eutrophication in the near future, although anthropogenic N sources, such as wastewater outfalls, may have significant local effects.
\end{abstract}

\section{Introduction}

The nitrogen $(\mathrm{N})$ cycle is a crucial underpinning of marine biological productivity (Gruber and Galloway, 2008). During the past $150 \mathrm{yr}$, the global $\mathrm{N}$ cycle has been dramatically changed by human activities that have loaded reactive $\mathrm{N}$ into ecosystems in amounts that rival natural sources (Rabalais, 2002; Galloway et al., 2004). Two main anthropogenic sources, the burning of fossil fuels and the fixation of atmospheric $\mathrm{N}$ via the Haber-Bosch process to produce fertilizer, have clearly altered the terrestrial $\mathrm{N}$ cycle globally (Galloway et al., 2004). While most anthropogenic $\mathrm{N}$ stays in the terrestrial ecosystem, a small component makes its way into the ocean (Gruber and Galloway, 2008). Anthropogenic $\mathrm{N}$ loading to the natural environment occurs predominantly along populated and industrial coasts, where it may lead to eutrophication, harmful algal blooms, and hypoxia as shown by studies of the Adriatic Sea (Justic et al., 1987), the Baltic Sea (Andersson and Rydberg, 1988; Conley et al., 2009), the East China Sea (Chen et al., 2007) and the Gulf of Mexico (Turner and Rabalais, 1994). In effect, humans have initiated an ocean $\mathrm{N}$ fertilization experiment. Although the experiment has not yet affected the open ocean's $\mathrm{N}$ cycle, it is already affecting some of the ocean's most productive locations - continental shelves.

Coastal seas receive $\mathrm{N}$ both from the open sea and from land. They are already disproportionately productive for their size due to natural nutrient sources, but additional $\mathrm{N}$ added by human activity can put them at risk of eutrophication. The likelihood that eutrophication will occur in any given location depends on site-specific characteristics like the natural 
supply of $\mathrm{N}$, the rate of exchange with the open ocean, and other potential controls on primary production such as phosphorus and solar radiation (light). An important foundation to assess the risk posed by human-derived $\mathrm{N}$ loadings at any given location is the production of a $\mathrm{N}$ budget that puts local sources into context.

In a global context, $\mathrm{N}$ budgets for coastal systems have been well-studied, particularly on the east coast of North America (Nixon et al., 1995; Boynton et al., 1995; Castro et al., 2003; Schaeffer et al., 2007). To date, coastal N budgets only exist for a few locations on the west coast of North America. These include the following: Tomales Bay (Smith and Hollibaugh, 1997), Elkhorn Slough (Caffrey et al., 2003; Chapin et al., 2004), Yaquina Bay (Kaldy, 2006), the Gulf of California (Sanchez-Carrillo et al., 2009), San Francisco Bay (Smith and Hollibaugh, 2006), and the Salish Sea (including Juan de Fuca Strait, Strait of Georgia (SoG), and Puget Sound; Mackas and Harrison, 2007). Only two (of the aforementioned six) study locations, San Francisco Bay and the Salish Sea, are sites likely to be affected by elevated N loadings due to human activity. As such, the remaining four locations are not suitable proxies to compare and evaluate the influence of human-derived N. Further, it is difficult to compare the influence of human-derived N between San Francisco Bay and the Salish Sea since their basin shape (e.g., depth and length) and exchange rates with the open ocean are very different (Mackas and Harrison, 1997; Smith and Hollibaugh, 2006). Nonetheless, the available data presented in the aforementioned studies suggest that advected Pacific Ocean water is the dominant source of dissolved $\mathrm{N}$ to coastal systems on the west coast of North America. In addition, the available data suggest that eutrophication, due to increases in $\mathrm{N}$ loading from human activities, is unlikely to occur on the west coast of North America.

The Strait of Georgia, a semi-enclosed coastal sea off the south-west coast of Canada (Fig. 1), receives $\mathrm{N}$ both from an increasing local human population of over 2 million residents (Statistics Canada, 2013), and from nutrient-rich, upwelled Pacific Ocean water that enters the strait through highly mixed tidal passages (Thomson, 1981; LeBlond, 1983; Masson, 2006). A concern that $\mathrm{N}$ loadings from local agriculture and wastewater discharge might lead to eutrophication of the strait led Mackas and Harrison (1997) to develop a budget for dissolved inorganic N (DIN) using available data for Juan de Fuca Strait, Puget Sound and the southern Strait of Georgia. They concluded that eutrophication due to anthropogenic loadings was unlikely, partly because the overwhelming input of DIN from the Pacific Ocean produced surface waters replete in $\mathrm{N}$ and partly because local primary production was generally light-limited. However, there is also a strong particulate N (PN) component for the cycle in the Strait of Georgia. To date, we have lacked a complete understanding of how the PN and DIN components interact, and the relative importance of processes like burial in sediments, or consumption and recycling in the water column. Furthermore, the northern

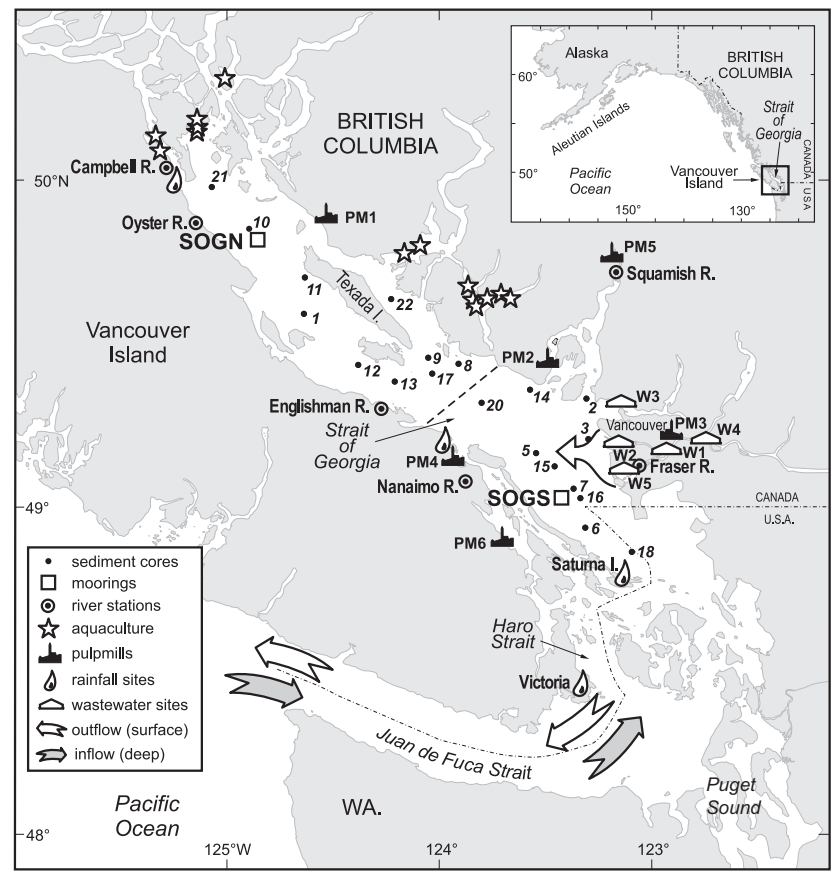

Fig. 1. Sampling locations in the Strait of Georgia for sediment box cores (small filled circle), sediment trap moorings samples (SOGS \& SOGN; open square), river samples (large open circle surrounding small, filled, black circle), aquaculture (open star), pulp mills (factory), atmospheric sampling stations (raindrop), and wastewater facilities (structure). The exact latitudes and longitudes for the sampling locations of the sediment box cores are given in the Supplement Table S1, and all other sampling locations are provided in Supplement Table S2. Pulp mill locations are identified by PM \# (PM1: Catalyst Paper; PM2: Port Mellon; PM3: New West Minister; PM4: Nanaimo; PM5: Squamish; and PM6: Crofton). Wastewater treatment plants are indicated by a W\# (W1: Annacis Island; W2: Iona Island; W3: Lions Gate, W4: Northwest Langley; W5 Lulu Island). The dashed line denotes the boundary between the northern and southern SoG.

reaches of the Strait of Georgia, which contain roughly half of the surface area and volume for the entire strait, have been neglected.

Here, we present new data for $\mathrm{N}$ from river sampling, water-column profiles, vertical flux in sediment traps, and dated sediment cores. These data, together with data from other sources, are used to construct budgets for particulate and dissolved $\mathrm{N}$ for the whole Strait of Georgia while distinguishing between marine and terrigenous components. We further constrain the PN cycle using isotopic $\left(\delta^{15} \mathrm{~N}\right)$ composition and discuss differences and connections between the northern and southern basins of the strait. Finally, we reexamine the potential for local human activities to produce eutrophic conditions within the Strait of Georgia. 


\section{Materials and methods}

\subsection{General approach}

The $\mathrm{N}$ budget was constructed using a combination of newly collected data (sediment cores, sediment traps, and nutrient measurements in rivers and seawater), previously published values, and unpublished data (atmospheric, wastewater, pulp mill, riverine, aquaculture, and population density) obtained from various government agencies. The uncertainty associated with each estimate is expressed as the standard deviation unless otherwise indicated.

\subsection{Sediment core data and the burial of total PN}

\subsubsection{Sample collection}

Twenty sediment cores were collected throughout the Strait of Georgia between 2002 and 2007 (Fig. 1) using a box corer or Pedersen corer at water depths of 76 to $388 \mathrm{~m}$ (Supplement S1). Cores were sub-sectioned on board the ship into $1 \mathrm{~cm}$ slices for the top $10 \mathrm{~cm}, 2 \mathrm{~cm}$ slices for the $10-20 \mathrm{~cm}$ section of the core, and $5 \mathrm{~cm}$ slices for the remainder of the core $(20$ to $\leq 50 \mathrm{~cm})$. Each slice was homogenized in a glass jar with a stainless steel spatula and stored in darkness at $-20^{\circ} \mathrm{C}$ prior to analysis. The sample collection, treatment, and analytical methods are detailed elsewhere (Johannessen et al., 2008).

\subsubsection{Radioisotope analysis and sedimentation rate}

A sub-sample from each depth interval was analyzed for ${ }^{210} \mathrm{~Pb}$ and ${ }^{226} \mathrm{Ra}$ activity by Flett Research Ltd. (Winnipeg, Manitoba, Canada) following the procedures of Eakins and Morrison (1978) and Mathieu et al. (1988). Sufficient counts were accumulated to maintain counting errors less than $3 \%$. Excess ${ }^{210} \mathrm{~Pb}$ activity was calculated by subtracting the activity of ${ }^{226} \mathrm{Ra}$. Sedimentation velocities $\left(\mathrm{cm} \mathrm{yr}^{-1}\right)$ and sediment accumulation rates $\left(\mathrm{g} \mathrm{cm}^{-2} \mathrm{yr}^{-1}\right)$ for each sediment core were determined from the core profiles of ${ }^{210} \mathrm{~Pb}$, by solving advective-diffusive equations, as described by Johannessen et al. (2003).

To extrapolate sedimentation rates to the entire Strait of Georgia, the sediment accumulation rate for each core was assigned to the depositional portion of the surrounding area (Fig. 1), which was estimated based on grain-size distribution. Specifically, mud and silt were taken to indicate deposition, and rock, gravel or sand to indicate erosion, except on the Fraser delta, where sand actively accumulates (Hill et al., 2008).

\subsubsection{Total PN and $\delta^{15} \mathrm{~N}$ analyses}

Total PN was measured in all particulate samples (core sediments, filters, sediment trap samples) at the University of British Columbia using a Carlo Erba CHN analyzer, follow- ing the procedure of Calvert et al. (1995). The analytical precision for this method was $\pm 3 \%$.

The $\mathrm{N}$ isotope compositions were measured using a VG PRISM IRMS equipped with an inline Carlo Erba CHN analyzer. The $\delta^{15} \mathrm{~N}$ was calculated according to the following formula:

$\delta^{15} N=1000\left[\left(R_{\mathrm{x}}-R_{\mathrm{std}}\right) / R_{\mathrm{std}}\right]$,

where $R$ is the atomic ratio of heavy $\left({ }^{15} \mathrm{~N}\right)$ and light $\left({ }^{14} \mathrm{~N}\right)$ isotopes of $\mathrm{N}\left({ }^{15} \mathrm{~N} /{ }^{14} \mathrm{~N}\right), x$ refers to the particulate samples and std is the atomic ratio of the heavy and light $\mathrm{N}$ isotopes of air. The $\mathrm{N}$ isotope composition is reported as $\delta^{15} \mathrm{~N}(\%)$, relative to air, with an analytical precision of $0.3 \%$.

\subsubsection{Nitrogen sediment surface flux, burial flux and remineralization rates}

The PN burial and remineralization rates in SoG sediments (Table 1) were calculated based on the methods described for organic carbon by Johannessen et al. (2003). Briefly, the burial flux for each core was calculated by multiplying the sediment accumulation rate (SAR, Table 1) by the concentration of PN ([PN]) in the deepest part of the core (Fig. 2). The surface flux was not calculated from the measured surface $[\mathrm{PN}]$ due to bio-mixing within the upper layers of the sediment cores. Instead we assumed that PN was converted to dissolved forms of $\mathrm{N}$ according to first-order kinetics, and thereby lost to the sediments. This loss was estimated by setting the integrated area under a theoretical exponential decay curve equal to the integrated total PN measured above the burial depth (the depth at which the [PN] becomes approximately constant). The rate of $\mathrm{N}$ remineralization for each core was calculated as the difference between the calculated surface flux and the burial flux. For reference, the in situ concentrations of $\mathrm{N}([\mathrm{N}])$, surface flux, burial flux, and oxidation flux are shown graphically in Fig. 3.

\subsection{Sediment trap data and total PN flux at $50 \mathrm{~m}$}

Total PN fluxes at $50 \mathrm{~m}$ were used to anchor the budget at mid-depth. Sinking particles were collected over 2008-2011 in the southern and northern Strait of Georgia (stations SOGS and SOGN; Fig. 1) using Baker sequential sediment traps (Baker et al., 1985) moored at $50 \mathrm{~m}$ depth. The cylindrical traps are $1 \mathrm{~m}$ high, with an internal diameter of $0.2 \mathrm{~m}$, and are baffled at the top to reduce mixing (Johannessen et al., 2005). Samples were sieved at sea $(500 \mu \mathrm{m}$ mesh) to remove swimming zooplankton, and the $<500 \mu \mathrm{m}$ fraction was stored frozen for later analysis. Sediment trap flux and composition data are shown in Table 2. Annual fluxes of PN were calculated for the $50 \mathrm{~m}$ isobath using surface areas of $3975 \mathrm{~km}^{2}$ and $3760 \mathrm{~km}^{2}$ estimated for the southern and northern parts of the strait, respectively. 
Table 1. Estimates of total PN fluxes derived from dated and modeled sediment box cores from the Strait of Georgia. The sediment accumulation rate is shown as SAR and PN concentration as [PN]. The depositional portion of the surrounding area, as described in Sect. 2.2.2, is denoted as "Area". Collection date, location, station, longitude, latitude, and water depth are provided in the Supplement S1.

\begin{tabular}{|c|c|c|c|c|c|c|c|c|c|}
\hline Station & $\begin{array}{r}\text { Area } \\
\left(\mathrm{km}^{2}\right)\end{array}$ & $\begin{array}{c}\text { SAR } \\
\left(\mathrm{g} \mathrm{cm}^{-2} \mathrm{yr}^{-1}\right)\end{array}$ & $\begin{array}{c}{[\mathrm{PN}]} \\
(\%)\end{array}$ & $\begin{array}{r}\text { PN flux }-\mathrm{s} \\
\left(\mu \mathrm{mol} \mathrm{cm}{ }^{-2} \mathrm{yr}^{-1}\right)\end{array}$ & $\begin{array}{l}\text { Irface } \\
\left(\mathrm{Mmol} \mathrm{yr}^{-1}\right)\end{array}$ & $\begin{array}{r}\text { PN flux }- \text { fin } \\
\left(\mu \mathrm{mol} \mathrm{cm}{ }^{-2} \mathrm{yr}^{-1}\right)\end{array}$ & $\begin{array}{l}1 \text { burial } \\
\left(\mathrm{Mmol} \mathrm{yr}^{-1}\right)\end{array}$ & PN flux - remineralization & $\left(\mathrm{Mmol} \mathrm{yr}^{-1}\right)$ \\
\hline GVRD 1 & 352 & 0.08 & 0.49 & 27 & 95 & 23 & 82 & 4 & 13 \\
\hline GVRD 2 & 114 & 0.26 & 0.15 & 28 & 31 & 16 & 18 & 12 & 14 \\
\hline GVRD 3 & 195 & 1.30 & 0.12 & 109 & 213 & 73 & 143 & 36 & 70 \\
\hline GVRD 5 & 385 & 0.64 & 0.20 & 91 & 351 & 71 & 274 & 20 & 77 \\
\hline GVRD 6 & 529 & 2.70 & 0.17 & 319 & 1689 & 243 & 1285 & 76 & 404 \\
\hline GVRD 7 & 216 & 0.32 & 0.13 & 29 & 63 & 18 & 40 & 11 & 23 \\
\hline GVRD 8 & 250 & 0.10 & 0.24 & 17 & 43 & 12 & 29 & 6 & 14 \\
\hline GVRD 9 & 123 & 0.17 & 0.26 & 31 & 38 & 24 & 30 & 7 & 8 \\
\hline GVRD 10 & 212 & 0.05 & 0.43 & 15 & 33 & 12 & 26 & 3 & 7 \\
\hline GVRD 11 & 393 & 0.12 & 0.41 & 35 & 137 & 29 & 113 & 6 & 24 \\
\hline GVRD 12 & 219 & 0.12 & 0.33 & 28 & 62 & 24 & 53 & 4 & 9 \\
\hline GVRD 13 & 117 & 0.12 & 0.31 & 27 & 31 & 22 & 26 & 5 & 5 \\
\hline GVRD 14 & 571 & 0.23 & 0.21 & 35 & 200 & 23 & 129 & 12 & 71 \\
\hline GVRD 15 & 255 & 1.73 & 0.20 & 243 & 620 & 186 & 473 & 57 & 146 \\
\hline GVRD 16 & 179 & 0.98 & 0.18 & 126 & 225 & 104 & 186 & 22 & 39 \\
\hline GVRD 17 & 98 & 0.21 & 0.27 & 40 & 39 & 30 & 29 & 10 & 10 \\
\hline GVRD 18 & 437 & 0.30 & 0.09 & 18 & 80 & 14 & 61 & 4 & 19 \\
\hline GVRD 20 & 293 & 0.10 & 0.21 & 15 & 43 & 12 & 34 & 3 & 9 \\
\hline GVRD 21 & 307 & 0.11 & 0.45 & 35 & 107 & 21 & 64 & 14 & 43 \\
\hline GVRD 22 & 157 & 0.23 & 0.35 & 57 & 89 & 45 & 70 & 12 & 18 \\
\hline North & 2225 & & & & 676 & & 523 & & 153 \\
\hline South & 3174 & & & & 3515 & & 2643 & & 872 \\
\hline Total & 5399 & & & & 4191 & & 3165 & & 1025 \\
\hline
\end{tabular}

\subsection{Water data for DIN and total PN in the SoG and rivers}

Seawater samples for DIN (only nitrate + nitrite measured for seawater) analysis were collected as a part of a field program established by the Department of Fisheries and Oceans and further described by Masson et al. (2006). Seawater DIN concentration data ([DIN]) were used in this study to calculate the advected DIN flux into and out of the SoG (see Sect. 2.6). Seawater samples were collected at 18 depths ( $0 \mathrm{~m}$ to $>400 \mathrm{~m}$ below surface) from 20 stations extending from Juan de Fuca Strait to the northern SoG. Sampling was quarterly (April, June/July, August/September and December/January) for $10 \mathrm{yr}$ (2001 to 2011). Samples were collected using Niskin bottles mounted on a rosette, subsampled into cleaned plastic tubes and frozen immediately. River samples were collected directly into plastic tubes from surface water away from the shore, and then immediately frozen. Samples were analyzed unfiltered using a Technicon AutoAnalyzer ${ }^{\mathrm{TM}}$ II at the Institute of Ocean Sciences, following the method described by Barwell-Clarke and Whitney (1996). The analytical precision for this method was $\pm 2 \%$.

River samples were analyzed for [DIN] and [PN] between 2008 and 2009 for the Fraser, Squamish, Campbell, Oyster, Englishman and Nanaimo rivers (Fig. 1; Table 3). Additional river data were obtained from Environment Canada for the Fraser River (at Hope, 1979-2006 and at Gravesend Reach, 2008-2011) and Squamish River
(2005) (Environment Canada's water quality website; Environment Canada, 2013b). The measured DIN concentrations were multiplied by each river's discharge (monthly and annual), while the concentration of $\mathrm{N}$ on the filtered particles was multiplied by the river's total particulate load to calculate the flux of PN (Table 3). River discharge data were provided by Environment Canada (2013b) for stations Englishman (08HB002), Fraser at Port Mann Pumping Station (08MH126) and Fraser at Hope (08MF005), Nanaimo (08HB034), Oyster (08HD011), Quinsam (08HD005, as a proxy for Campbell River), and Squamish near Brackendale (08GA022) (Fig. 1). Published values were used for the total annual particle load data for the Fraser (Thomas and BendellYoung, 1999) and Squamish rivers (Hickin, 1989). The estimated particulate load for the other rivers was based on the remainder of a particulate budget constructed by Johannessen et al. (2003), the discharge rates of the rivers, and the known relationship between the particulate load and discharge rate for the Squamish River (Hickin, 1989).

\subsection{Atmospheric deposition of $\mathbf{N}$ to the SoG}

Precipitation, atmospheric concentrations and $\mathrm{N}$ flux data (Table 4) were provided by Environment Canada (2013a). Rainwater $\mathrm{NO}_{3}$ and $\mathrm{NH}_{4}$ concentrations ([NO 3$]$ and $\left[\mathrm{NH}_{4}\right]$ ) are available from several locations adjacent to the SoG (Campbell River, Nanaimo, Victoria, Saturna). Dry deposition (PN) data, available only for the Saturna Island site 
Table 2. Flux-weighted average daily $\mathrm{N}$ and total and annual flux of sinking particles in the Strait of Georgia based on sediment traps deployed between 2008 and 2011. Sediment accumulation rates at the two sites are based on box cores collected at GVRD 16 and GVRD 10 , respectively. The data are represented as weighted averages (range) or \pm standard error.

\begin{tabular}{l|rr|rr}
\hline & \multicolumn{2}{|c|}{ SOGS $-50 \mathrm{~m}^{\mathrm{a}}$} & \multicolumn{2}{c}{ SOGN $-50 \mathrm{~m}^{\mathrm{b}}$} \\
\hline $\mathrm{N}$ daily flux $\left(\mathrm{g} \mathrm{m}^{-2} \mathrm{~d}^{-1}\right)$ & 0.03 & $(0.002-0.20)$ & 0.017 & $(0.0005-0.071)$ \\
{$[\mathrm{N}](\%)$} & 0.3 & $(0.10-2.2)$ & 1.0 & $(0.06-3.1)$ \\
$\mathrm{N}$ annual flux $\left(\mathrm{Mmol} \mathrm{yr}^{-1}\right)$ & 3020 & $(196-19605)$ & 1776 & $(52-7358)$ \\
Total, annual trap flux $\left(\mathrm{g} \mathrm{m}^{-2} \mathrm{yr}^{-1}\right)$ & 4122 & $(2102-7346)$ & 701 & $(101-1140)$ \\
Sediment fluxes $\left(\mathrm{g} \mathrm{m}^{-2} \mathrm{yr}^{-1}\right)$ at same location & 9800 & & 500 & \\
$\delta^{15} \mathrm{~N}(\% \circ)$ & 6.6 & \pm 0.2 & 8.2 & \pm 0.2 \\
\hline
\end{tabular}

a Strait of Georgia south station (Fig. 1); ${ }^{\text {b }}$ Strait of Georgia north station

Table 3. Discharge rates, $\left[\mathrm{NO}_{3}\right]+\left[\mathrm{NO}_{2}\right]$ and particulate nitrogen $[\mathrm{PN}]$, and calculated fluxes for DIN and PN from rivers entering the SoG. Numerical values for each flux are represented as the weighted-average (range). The range of values represents the min and max of the concentration data collected over a one-year period. The $\delta^{15} \mathrm{~N}$ composition is represented by the average \pm standard deviation. Data not available: na.

\begin{tabular}{lrrrrrr}
\hline Station & $\begin{array}{r}\text { Monthly discharge } \\
\left(\mathrm{m}^{3} \mathrm{~s}^{-1}\right)\end{array}$ & $\left.\begin{array}{r}{\left[\mathrm{NO}_{3}\right]+\left[\mathrm{NO}_{2}\right]} \\
(\mu \mathrm{mol} \mathrm{L}\end{array}\right)$ & $\begin{array}{r}\mathrm{DIN} \\
\left(\mathrm{Mmol} \mathrm{yr}^{-1}\right)\end{array}$ & $\begin{array}{r}\mathrm{PN} \\
\left(\mu \mathrm{g} \mathrm{L}{ }^{-1}\right)\end{array}$ & $\begin{array}{r}\mathrm{PN} \\
\left(\mathrm{Mmol} \mathrm{yr}^{-1}\right)\end{array}$ & $\begin{array}{r}\mathrm{PN}-\delta^{15} \mathrm{~N} \\
(\% o)\end{array}$ \\
\hline Fraser & $3620(1780-8590)$ & $4.5-11.2$ & $1662(1184-2252)$ & $213-266$ & $1954(1737-2171)$ & $1.7 \pm 0.2$ \\
Squamish & $242(87.5-492)$ & $3.4-6.0$ & $37(21-41)$ & $920-1210$ & $561(502-656)$ & $-0.5 \pm 1.5$ \\
Campbell & $8.54(2.2-16.7)$ & $2.9-5.2$ & $0.8(0.2-1.1)$ & $1177-1279$ & $22.7(21.7-23.7)$ & $3.4 \pm 0.3$ \\
Oyster & $13.9(3.1-18.2)$ & $1.9-3.5$ & $1.0(0.6-1.2)$ & $567-634$ & $19.0(18.0-19.9)$ & na \\
Englishman & $13.1(1.4-27.0)$ & $2.1-3.4$ & $0.7(0.5-0.9)$ & $680-727$ & $20.8(20.1-21.4)$ & na \\
Nanaimo & $39.8(5.9-76)$ & $1.7-5.3$ & $4.0(1.0-6.8)$ & $980-1072$ & $92.0(87.7-95.9)$ & na \\
\hline
\end{tabular}

(Fig. 1), were extrapolated to the whole Strait of Georgia. In support of this extrapolation, the [DIN] data for all of the sites adjacent to the SoG during the year 2003 are also provided in Table 4 . There are clearly regional differences in the atmospheric [DIN] (34.7-89.7 $\left.\mathrm{Mmol} \mathrm{yr}^{-1}\right)$, but the values are all of the same order of magnitude and are negligible in the context of the whole $\mathrm{N}$ budget.

\subsection{Advection}

The advective transport of DIN into the SoG was determined based on salt balance, following the methodology described in detail by Gordon et al. (1996), and using the following equation:

$V_{\mathrm{In}}=\frac{S_{\mathrm{O}} V_{\mathrm{Fw}}}{S_{\mathrm{In}}-S_{\mathrm{O}}}$,

where $V_{\text {In }}$ and $S_{\text {In }}$ are the volume flux and salinity of the deep shoreward estuarine flow into the SoG, $V_{\mathrm{Fw}}$ is the volume flux of freshwater to the SoG, and $S_{\mathrm{O}}$ is the salinity of the out-flowing surface layer. The volume flux of the estuarine circulation $\left(V_{\text {In }}\right)$ was estimated to be $7.8 \times 10^{9} \mathrm{~m}^{3}$ day $^{-1}$ $\left( \pm 5.0 \times 10^{9} \mathrm{~m}^{3} \mathrm{day}^{-1}\right)$ based on a freshwater volume flux $\left(V_{\mathrm{FW}}\right)$ of $0.43 \times 10^{9} \mathrm{~m}^{3} \mathrm{day}^{-1}\left( \pm 0.01 \times 10^{9} \mathrm{~m}^{3} \mathrm{day}^{-1}\right)$, seaward salinity $\left(S_{\mathrm{O}}\right)$ of $31( \pm 0.6)$ and shoreward salinity $\left(S_{\mathrm{In}}\right)$ of 32.7 ( \pm 0.9$)$. The freshwater flux was based on the Fraser
River contributing $73 \%$ to the freshwater budget (Johannessen et al., 2003) at $3620 \mathrm{~m}^{3}$ day $^{-1}$. The input of DIN to the SoG is then simply calculated as

$\mathrm{DIN}_{\text {In }} \times V_{\mathrm{In}}$,

where $\mathrm{DIN}_{\text {In }}$ is the mean $\left[\mathrm{NO}_{3}\right]\left(29.8 \pm 4.2 \mu \mathrm{mol} \mathrm{L}{ }^{-1}\right.$, S.D. $)$ of incoming deep water (> $50 \mathrm{~m}$ depth from the Juan de Fuca Strait). This provides an estimate for the advective transport of DIN into the Salish Sea $\left(85300 \pm 55700 \mathrm{Mmol} \mathrm{yr}^{-1}\right)$. According to Mackas and Harrison (1997), only $35 \%$ of this advected dissolved $\mathrm{NO}_{3}$ will reach the SoG.

Similarly, the advective transport of DIN out of the SoG is calculated as

$V_{\text {Out }}=V_{\text {In }}+V_{\mathrm{Fw}}$,

where $V_{\mathrm{In}}$ and $V_{\mathrm{Fw}}$ are estimated based on Eqs. (2) and (3). $V_{\text {Out }}$ was determined to be $8.3 \times 10^{9} \mathrm{~m}^{3}$ day $^{-1}$ $\left( \pm 5.0 \times 10^{9} \mathrm{~m}^{3} \mathrm{day}^{-1}\right)$ using Eq. (4) and based on the estimates of $V_{\text {In }}$ (Eq. 5). The output of DIN to the SoG is then simply calculated as

$\mathrm{DIN}_{\text {Out }} \times V_{\text {Out }}$,

where $N_{\text {Out }}$ is the mean $\left[\mathrm{NO}_{3}\right]\left(23.0 \pm 4.6 \mu \mathrm{mol} \mathrm{L}{ }^{-1}\right.$, S.D. $)$ of outgoing surface water ( $<30 \mathrm{~m}$ depth) from the Juan de Fuca Strait. This provides an estimate for the advective transport 
Table 4. Atmospheric dissolved inorganic nitrogen concentration [DIN], particulate nitrogen concentration [PN], and total annual atmospheric deposition to SoG for years between 2002 and 2009 for Saturna Island and Vancouver Island stations (Environment Canada, 2013c). Data not available: na.

\begin{tabular}{lccrrrrrrr}
\hline & Year & $\begin{array}{c}\text { Rainfall } \\
\left(\mathrm{cm} \mathrm{yr}^{-1}\right)\end{array}$ & \multicolumn{2}{c}{$\begin{array}{c}\text { Dissolved } \\
\left(\mathrm{Mmol} \mathrm{yr}^{-1}\right)\end{array}$} & \multicolumn{2}{c}{$\begin{array}{c}\text { Particulate } \\
\left(\mathrm{Mmol} \mathrm{yr}^{-1}\right)\end{array}$} & $\begin{array}{r}\text { Dissolved } \\
\left(\mathrm{Mmol} \mathrm{yr}^{-1}\right)\end{array}$ & $\begin{array}{r}\text { Particulate } \\
\left(\mathrm{Mmol} \mathrm{yr}^{-1}\right)\end{array}$ & $\begin{array}{r}\text { Total } \\
\left(\mathrm{Mmol} \mathrm{yr}^{-1}\right)\end{array}$ \\
Station & & & $\mathrm{NH}_{4}$ & $\mathrm{NO}_{3}$ & $\mathrm{NH}_{4}$ & $\mathrm{NO}_{3}$ & $\mathrm{NH}_{4}+\mathrm{NO}_{3}$ & $\mathrm{NH}_{4}+\mathrm{NO}_{3}$ & $\mathrm{NH}_{4}+\mathrm{NO}_{3}$ \\
\hline Saturna Island & 2002 & 60 & 30.8 & 55.0 & 8.6 & 14.5 & 85.8 & 23.1 & 108.9 \\
Saturna Island & 2003 & 81 & 29.6 & 60.1 & 8.6 & 14.8 & 89.7 & 23.4 & 113.0 \\
Saturna Island & 2004 & 79 & 37.5 & 78.6 & 8.8 & 14.0 & 116.1 & 22.8 & 138.9 \\
Saturna Island & 2005 & 76 & 27.5 & 54.8 & 10.4 & 15.0 & 82.3 & 25.3 & 107.7 \\
Saturna Island & 2006 & 88 & 32.0 & 65.2 & 6.0 & 12.5 & 97.2 & 18.5 & 115.7 \\
Saturna Island & 2007 & 93 & 42.1 & 76.4 & 6.6 & 11.9 & 118.5 & 18.5 & 137.0 \\
Saturna Island & 2009 & 81 & 29.7 & 54.1 & na & na & 83.8 & na & $>83.8$ \\
Campbell River & 2003 & 46 & 30.1 & 50.0 & na & na & 80.1 & na & $>80.1$ \\
Nanaimo & 2003 & 48 & 21.5 & 42.5 & na & na & 64.0 & na & $>64.0$ \\
Victoria & 2003 & 41 & 9.0 & 25.6 & na & na & 34.7 & na & $>34.7$ \\
\hline
\end{tabular}

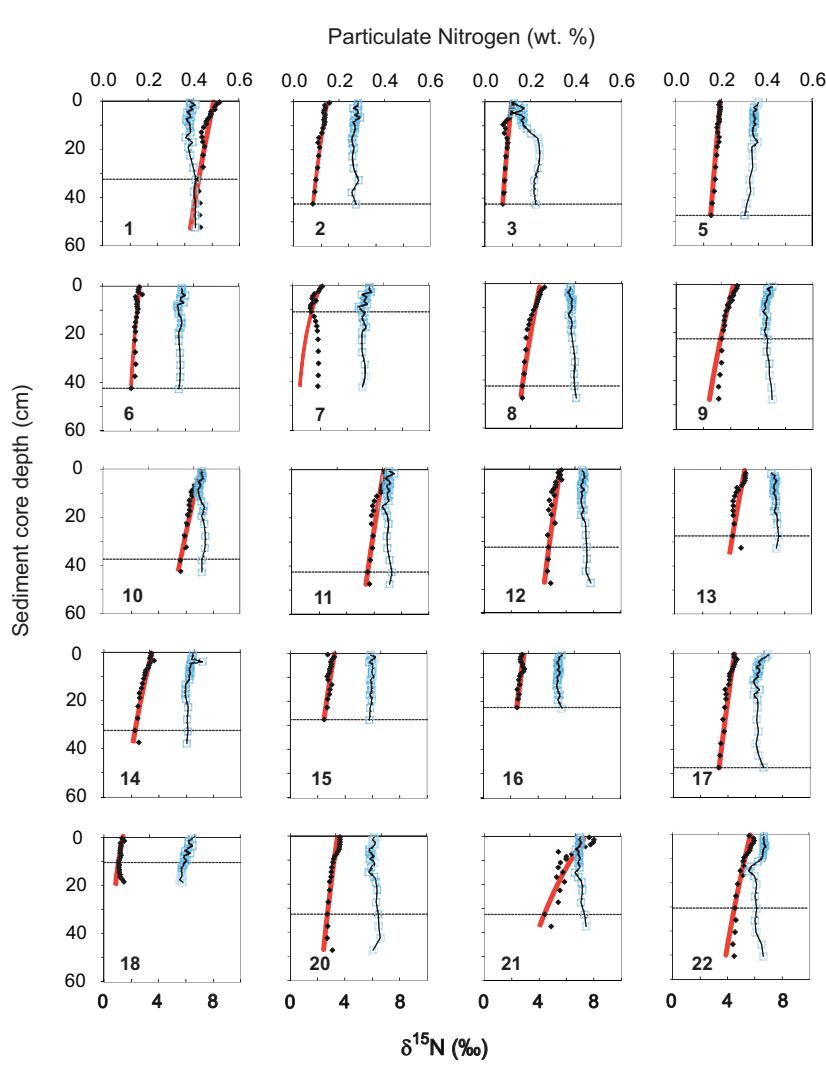

Fig. 2. Depth profiles for total particulate nitrogen concentration ([PN]) measured as weight \% (wt. \%, black solid diamond) and $\delta^{15} \mathrm{~N}$ composition of sediment (blue open square connected by solid black line) for all 20 box cores used in this study. The horizontal dashed line for each sediment profile represents the burial depth (the depth at which the [PN] becomes approximately constant). The solid red line that follows the [PN] depth profiles represents the theoretical exponential decay curve described in Sect. 2.2.4. of DIN out of the Salish Sea $\left(69500 \pm 44200 \mathrm{Mmol} \mathrm{yr}^{-1}\right)$. However, only $35 \%$ of this advected dissolved $\mathrm{NO}_{3}$ is from the SoG (Mackas and Harrison, 1997).

\subsection{Primary production in the SoG (conversion of DIN to $\mathbf{P N}$ )}

Primary production (PP) converts DIN to marine particulate nitrogen $\left(\mathrm{PN}_{\mathrm{Mar}}\right)$ within the water column of the SoG. The PP rate for the SoG was previously assessed by Harrison et al. (1983) to be $\sim 280 \mathrm{gC} \mathrm{m}^{-2} \mathrm{yr}^{-1}$. This PP rate was converted to $\mathrm{PN}_{\mathrm{Mar}}$ using a $\mathrm{C}: \mathrm{N}$ ratio of $6.6: 1$ (Redfield et al., 1963). The calculated $\mathrm{PN}_{\mathrm{Mar}}$ implies a total production of $23400 \mathrm{Mmol} \mathrm{yr}^{-1} \mathrm{PN}_{\mathrm{Mar}}$ for the entire strait assuming a surface area of $7735 \mathrm{~km}^{2}$. There are other estimates of PP for the Strait of Georgia that range from 120 to $>400 \mathrm{gC} \mathrm{m}^{-2} \mathrm{yr}^{-1}$ (Parsons et al., 1970, 1980, 1981; Stockner et al., 1979; Pawlowicz et al., 2007). However, the particulate nitrogen budget could only be balanced if the PP rate was constrained to 260 to $300 \mathrm{gC} \mathrm{m}^{-2} \mathrm{yr}^{-1}$ (see below for constraints in Sect. 3.1). The flux of $\mathrm{PN}_{\mathrm{Mar}}$ at $50 \mathrm{~m}$ (the location of the sediment traps) and at the bottom (variable depths) as a result of this surface PP was estimated using an empirical relationship accounting for the remineralization of $\mathrm{N}$ with depth (Pace et al., 1987):

$\mathrm{PN}_{\mathrm{Mar}}=0.432\left(z^{-0.843} \cdot \mathrm{PP}^{1.123}\right)$,

where $z$ is the depth (m) in the water column.

\subsection{Wastewater effluent}

The input of total N (PN and DIN) from Vancouver wastewater into the SoG was estimated from the effluent loadings at the Lions Gate and Iona wastewater facilities (Table 5). Loadings for Annacis, Lulu and Northwest wastewater treatment facilities were not included in this budget, since these 

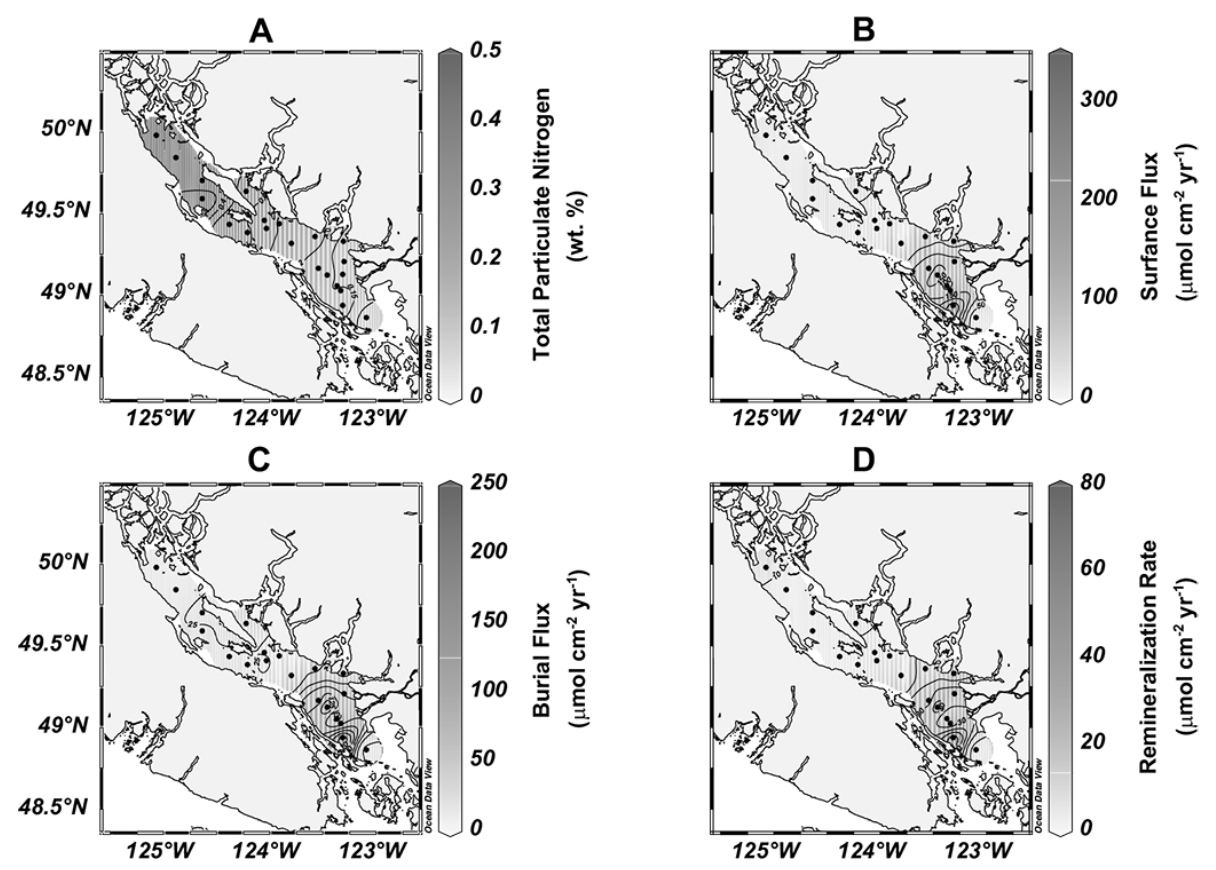

Fig. 3. A contour plot of sediment core data for the Strait of Georgia showing (a) total particulate nitrogen (PN) concentration (\%) for surface

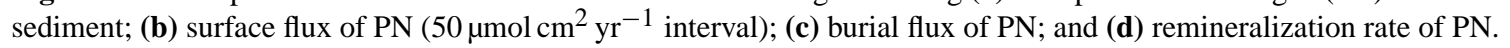

facilities discharge into the Fraser River upstream of the sampling sites. Similarly, the mean input of total N (PN and DIN) from the 2 largest wastewater facilities on Vancouver Island (Clover Point and Macaulay Point) is less than $100 \mathrm{Mmol} \mathrm{yr}^{-1}$ and was not included in this budget. These two Vancouver Island facilities are unlikely to influence the $\mathrm{N}$ flux to the Strait of Georgia, since they discharge into Juan de Fuca Strait and would be overwhelmed by the advected DIN flux.

\subsection{Pulp mill effluent}

Pulp mill effluent loading data were obtained from the Environmental Monitoring System Web Reporting website administered by the British Columbia Ministry of Environment (2013). The input of total $\mathrm{N}$ from pulp mill activities adjacent to the SoG was calculated from the reported effluent loadings for the facilities at Powell River (Catalyst Paper; $84 \pm 18 \mu \mathrm{mol} \mathrm{L}^{-1}, 6.5 \times 10^{10} \mathrm{~L} \mathrm{yr}^{-1}$; Table 5) and Port Mellon (Howe Sound Pulp and Paper; $56 \pm 18 \mu \mathrm{mol} \mathrm{L}{ }^{-1}$, $2.9 \times 10^{10} \mathrm{~L} \mathrm{yr}^{-1}$; Table 5). Although there are other active, or recently active, pulp mill operations adjacent to the SoG, including sites in New Westminster (Kruger Products LP), Nanaimo (Nanaimo Forest Products), Squamish (Western Woodfibre - closed) and Crofton (Catalyst), there is no requirement to collect DIN or PN data. Consequently, the pulp mills lacking PN and DIN data were assigned the average of the Powell River and Port Mellon fluxes.

\subsection{Aquaculture}

The maximum input of TN (PN + DIN) from aquaculture production affecting the SoG (Table 5) was calculated from the licensed total maximum production for every aquaculture facility located within or adjacent to the SoG (Department of Fisheries and Oceans, 2013). The license numbers reviewed include AQ 137, AQ 138, AQ 216, AQ 221, AQ 304, AQ 332, AQ 408, AQ 412 AQ 547, AQ 572, AQ 746, AQ 1697, AQ 1698 and AQ 1770. TN input to the surrounding environment was estimated to be $\sim 10 \%$ (dissolved $6.7 \%$ and particulate $3.4 \%$ ) of the total aquaculture production $\left(79 \mathrm{Mmol} \mathrm{yr}^{-1}\right.$; Hall et al., 1992). Although the PN $\left(26 \mathrm{Mmol} \mathrm{yr}^{-1}\right)$ in aquaculture is not produced autochthonously, the fish meal used to feed fish would carry a marine signature $\left(\delta^{15} \mathrm{~N}=10 \%\right.$; Sutherland et al., 2006). Therefore, we consider PN from aquaculture to be $\mathrm{PN}_{\mathrm{Mar}}$. Furthermore, we assume that the $\mathrm{PN}_{\mathrm{Mar}}$ due to finfish aquaculture would remineralize to DIN with depth at the same rate as PN produced by PP (Sect. 2.7).

\subsection{Isotopic mass balance}

As an additional constraint of the PN budget, we weighted particulate fluxes by the associated stable $\mathrm{N}$ isotope compositions $\left(\delta^{15} \mathrm{~N}\right)$ thereby ensuring that the system was isotopically balanced. In addition to our measured $\delta^{15} \mathrm{~N}$ composition of particulate matter from sediment trap and riverine samples, we were provided $\delta^{15} \mathrm{~N}$ composition data for the Iona wastewater treatment facility (2008-2012). We also incorporated published values available for pulp mill effluent 
Table 5. Summary of dissolved inorganic nitrogen (DIN), particulate nitrogen (PN) and total N (TN) inputs to the SoG from terrigenous and marine sources. Data not available: na.

\begin{tabular}{lrrrr}
\hline Source & $\begin{array}{r}\mathrm{DIN} \\
\left(\mathrm{Mmol} \mathrm{yr}^{-1}\right)\end{array}$ & $\begin{array}{r}\mathrm{DIN}^{\mathrm{a}} \\
\left(\mathrm{Mmol} \mathrm{yr}^{-1}\right)\end{array}$ & $\begin{array}{r}\mathrm{PN} \\
\left(\mathrm{Mmol} \mathrm{yr}^{-1}\right)\end{array}$ & $\begin{array}{r}\mathrm{TN} \\
\left(\mathrm{Mmol} \mathrm{yr}^{-1}\right)\end{array}$ \\
\hline Terrigenous & & & & \\
\hline Fraser River & 1662 & 1304 & 1954 & 3616 \\
Other major rivers & 37 & na & 716 & 753 \\
Atmosphere & 85 & 188 to 256 & 21.9 & 120 \\
Pulp mills & 20 & na & 5 & 25 \\
Groundwater & 130 to $391^{\mathrm{a}}$ & 130 to 391 & na & na \\
\hline Marine & & & 260 & $30160 \pm 19500$ \\
\hline Advection via Haro Strait & $29900 \pm 19500$ & 27840 & 23400 & 23400 \\
Total PP & $160(133-188)$ & 522 to 574 & $38(37-39)$ & $198(170-227)$ \\
Wastewater & 53 & na & 26 & 79 \\
Aquaculture & & & \\
\hline
\end{tabular}

${ }^{a}$ Mackas and Harrison (1997) estimates; ${ }^{b}$ data from Metro Vancouver, Iona outfall

(0\%); Oakes et al., 2010), atmospheric deposition $(\sim 6 \%$; Freyer, 1991; Garten, 1996; Elliott et al., 2009), and aquaculture ( $\sim 10 \%$; Sutherland et al., 2006). We lacked data to do the same for DIN.

Estimates of $\delta^{15} \mathrm{~N}$ composition were determined for components of the $\mathrm{PN}_{\mathrm{Ter}}$ and $\mathrm{PN}_{\mathrm{Mar}}$ budgets that were not directly measured or assigned a value by the literature (e.g., $\mathrm{PN}_{\text {Mar }}$ ). The $\delta^{15} \mathrm{~N}$ composition for these estimates was determined by mass balance. The constraints placed on these estimates of $\delta^{15} \mathrm{~N}$ composition are described in detail in Sect. 3.1.

\subsection{Calculation of propagated uncertainty}

The uncertainties (standard deviations) for budget terms determined from a calculation, such as the advective transport of DIN into and out of the SoG, were determined by propagating their uncertainties. Uncertainties were propagated onto the final calculated results using a linear approximation (a first-order Taylor series expansion). This is the standard method for propagating uncertainties through a function onto a derived quantity (e.g., Bevington and Robinson, 2003; JCGM, 2008).

\section{Nitrogen budgets for the SoG}

\subsection{Constraints on the PN budget}

We have created $\mathrm{N}$ budgets independently for the southern and northern basins of the strait (Fig. 4a) because the Fraser particles contribute a significant portion of bottom sediment only for the southern basin, south of Texada Island (Hill et al., 2008). Much of the Fraser River particulate material trav- els southward in a plume extending from the delta, then enters Haro Strait where it is mixed throughout the water column by the strong tidal currents (Johannessen et al., 2005). A portion of this material returns to the strait at depth and travels northward near the bottom (Johannessen et al., 2005). The re-entry of $\mathrm{PN}$ by this pathway $\left(1709 \mathrm{Mmol} \mathrm{yr}^{-1}\right.$ ) explains why the flux of particles to bottom sediment in the southern Strait of Georgia is so much higher than that captured by the $50 \mathrm{~m}$ sediment trap moored close to the center of the southern strait (Fig. 1). The $\mathrm{PN}_{\text {Terr }}$ associated with this returning transport, therefore, does not represent an exclusively external source, but rather a longer transport pathway for Fraser River particulate $\mathrm{N}$ with the addition of some material from outside.

The following constraints enabled the flux estimates of $\mathrm{PN}_{\text {Terr }}$ and $\mathrm{PN}_{\mathrm{Mar}}$ to be determined within the water column and in sediment.

1. The $\delta^{15} \mathrm{~N}$ composition of $\mathrm{PN}_{\mathrm{Mar}}$ must be heavier than $\mathrm{PN}_{\text {Terr }}$ (Sigman and Casciotti, 2001). The heaviest $\delta{ }^{15} \mathrm{~N}$ signature for a mixture of $\mathrm{PN}_{\mathrm{Mar}}$ and $\mathrm{PN}_{\text {Terr }}$ will reflect the lightest possible value for $\mathrm{PN}_{\mathrm{Mar}}$. Therefore, the $\delta^{15} \mathrm{~N}$ composition for $\mathrm{PN}_{\text {Mar must be greater than }}$ $8.2 \pm 0.2 \%$ (standard error, $n=75$ ); the flux-weighted average $\delta^{15} \mathrm{~N}$ composition of particulate samples from the SOGN sediment trap (Table 2).

2. The total PN flux to the sediment is $676 \mathrm{Mmol} \mathrm{yr}^{-1}$ and $3515 \mathrm{Mmol} \mathrm{yr}^{-1}$ for the northern and southern SoG, respectively (Table 1 ). Therefore, the $\mathrm{PN}_{\text {Mar }}$ flux to the sediment must be less than or equal to $676 \mathrm{Mmol} \mathrm{yr}^{-1}$ and $3515 \mathrm{Mmol} \mathrm{yr}^{-1}$ for the northern and southern SoG, respectively.

3. The $\delta^{15} \mathrm{~N}$ composition of the sediment is $6.9 \pm 0.1 \%$ o (standard error, $n=10$ ) and $5.3 \% \circ \pm 0.1 \%$ (standard 

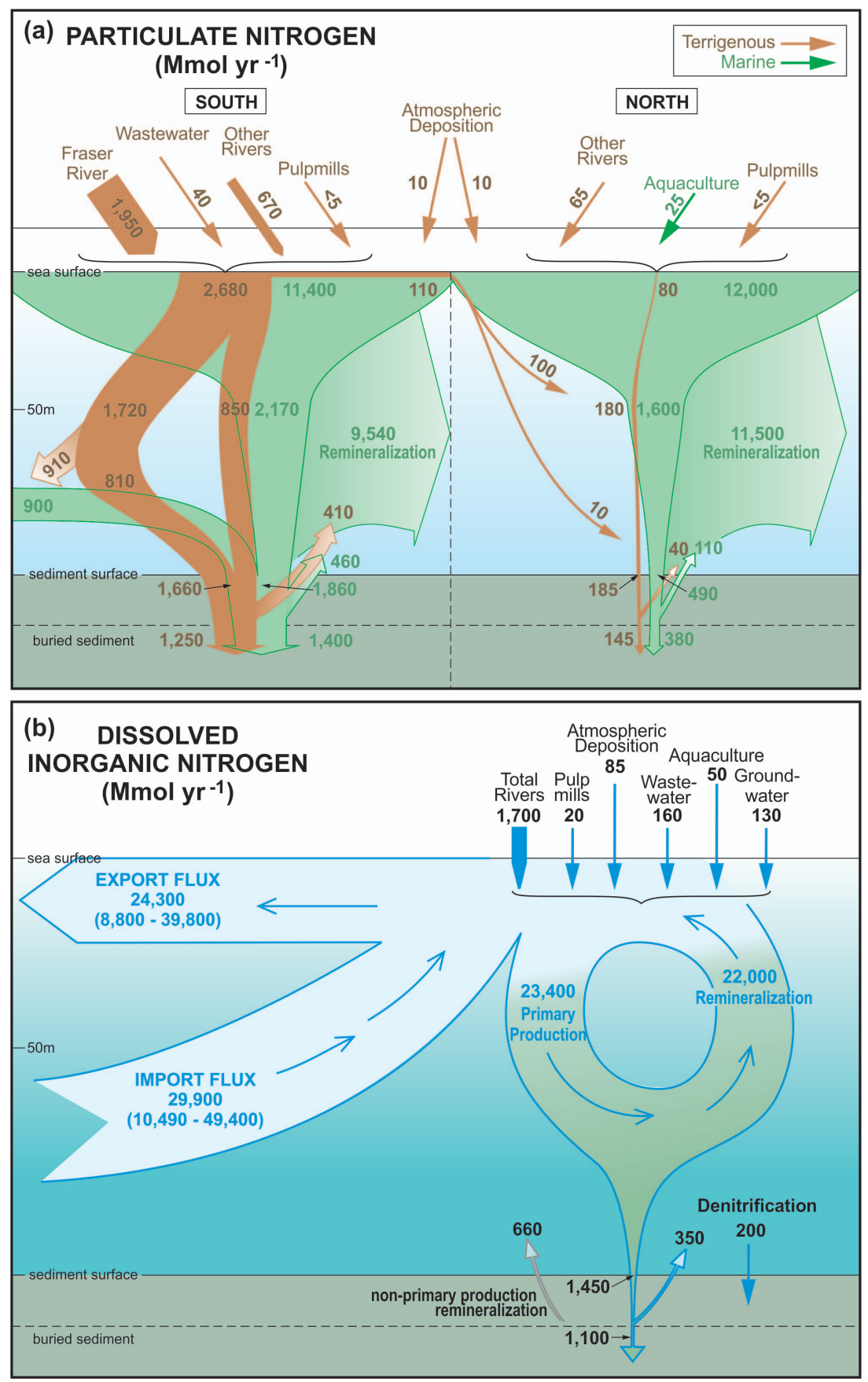

Fig. 4. Schematic diagrams of the nitrogen cycle in the Strait of Georgia (SoG) showing budgets for (a) particulate nitrogen and (b) dissolved inorganic nitrogen (DIN). Southern (left) and northern (right) regions of the strait are presented separately in (a) to highlight the large difference in the terrigenous particulate nitrogen contributions and sources between the two basins. Brown arrows indicate terrigenous particulate nitrogen $\left(\mathrm{PN}_{\mathrm{Terr}}\right)$ fluxes and green arrows marine $\left(\mathrm{PN}_{\mathrm{Mar}}\right)$ fluxes. Fading toward the head of an arrow indicates remineralization. Remineralization in this figure includes only the transformation of PN to DIN. Arrows show PN fluxes in $\mathrm{Mmol} \mathrm{yr}^{-1}$, as indicated by the number written beside the arrow, which also has width scaled according to the size of the flux. Fluxes of PN and DIN were estimated independently for several components within the budget including sources (e.g., rivers, wastewater, aquaculture, etc.), vertical PN flux (surface, $50 \mathrm{~m}$ depth) and fluxes into and out of sediments (flux to sediment surface and burial flux). For example, the net export of PN $\mathrm{N}_{\mathrm{Ter}}$ from southern

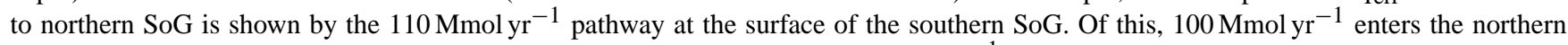
SoG above $50 \mathrm{~m}$ depth, as indicated by sediment traps, and the remaining $10 \mathrm{Mmol} \mathrm{yr}^{-1}$ enters deeper water. Likewise, remineralization of $910 \mathrm{Mmol} \mathrm{yr}^{-1}$ of $\mathrm{PN}_{\mathrm{Ter}}$ within the shallower parts of southern SoG is partially offset by the import of $900 \mathrm{Mmol} \mathrm{yr}^{-1} \mathrm{of} \mathrm{PN}_{\mathrm{Mar}}$ from outside the southern boundary of the strait. 
error, $n=10$ ) for the northern and southern SoG, respectively, representing a mixture of $\mathrm{PN}_{\mathrm{Mar}}$ and $\mathrm{PN}_{\text {Terr }}$.

4. The rate of PP for both the northern and southern SoG is the same. Although the rate of PP has only been measured in the southern SoG (Harrison et al., 1983), there is evidence that supports the assumption that PP rates are similar for both the northern and southern SoG including the following: (a) the concentration of chlorophyll $\left(\mathrm{mg} \mathrm{m}^{-3}\right)$ is regionally equivalent on an annual, seasonal and depth-integrated basis (Masson and Pena, 2009); (b) water column profiles for $\mathrm{NO}_{3}$ are regionally indistinguishable both annually and seasonally (Masson, 2006); (c) chlorophyll $a$ concentrations, derived from satellite imagery, indicate that PP is equivalently active in the southern and northern SoG (Gower et al., 2013); (d) the PP rates are constrained by total organic matter and nitrogen and carbon isotope composition of particles collected in the sediment traps and sediment samples.

5. The average rate of PP must be $280 \mathrm{gC} \mathrm{m}^{-2} \mathrm{yr}^{-1}$ for the entire SoG, with a range of 260 to $300 \mathrm{gC} \mathrm{m}^{-2} \mathrm{yr}^{-1}$. The PP rate cannot exceed $300 \mathrm{gC} \mathrm{m}^{-2} \mathrm{yr}^{-1}$ based on constraints (1), (2) and (3) requiring $\mathrm{PN}_{\mathrm{Mar}}$ to have a $\delta^{15} \mathrm{~N}$ composition greater than $8.2 \%$. The total PN flux to the sediment in the northern SoG must be $676 \mathrm{Mmol} \mathrm{yr}^{-1}$, and the $\delta^{15} \mathrm{~N}$ composition of the sediment must be $6.9 \pm 0.1 \%$ in the northern SoG, respectively. A PP rate of $300 \mathrm{gC} \mathrm{m}^{-2} \mathrm{yr}^{-1}$ yields $530 \mathrm{Mmol} \mathrm{yr}^{-1}$ of PN to the sediments in the southern SoG based on Eq. (6). This production rate leaves $176 \mathrm{Mmol} \mathrm{yr}^{-1}$ to carry a terrigenous $\delta^{15} \mathrm{~N}$ signature of $\sim 2.5 \%$ o $\left(77 \mathrm{Mmol} \mathrm{yr}^{-1}\right.$ at $3.7 \%$ - northern inputs; $74 \mathrm{Mmol} \mathrm{yr}^{-1}$ at $1.1 \%$ - advection of material from the southern SoG). A PP rate greater than $300 \mathrm{gC} \mathrm{m}^{-2} \mathrm{yr}^{-1}$ would generate a $\delta^{15} \mathrm{~N}$ composition greater than $7.0 \%$, violating constraint (3). Similarly, the PP rate cannot be less than $260 \mathrm{gC} \mathrm{m}^{-2} \mathrm{yr}^{-1}$ because it disallows $\mathrm{PN}_{\mathrm{Mar}}$ and $\mathrm{PN}_{\text {Terr }}$ to balance. Further, a rate of $260 \mathrm{gC} \mathrm{m}^{-2} \mathrm{yr}^{-1}$ requires the $\delta^{15} \mathrm{~N}$ composition of $\mathrm{PN}_{\mathrm{Mar}}$ to be assigned a value of $9 \%$. The PN budget cannot be balanced with a PP rate of $260 \mathrm{gC} \mathrm{m}^{-2} \mathrm{yr}^{-1}$ and a value $<9 \%$. Therefore, we conclude that PP is $280 \pm 20 \mathrm{gC} \mathrm{m}^{-2} \mathrm{yr}^{-1}$.

Based upon the constraints mentioned above and endmember data for $\mathrm{PN}_{\mathrm{Mar}}(8.7 \pm 0.3 \%$ ) from Johannessen et al. (2005), the $\delta^{15} \mathrm{~N}$ composition for $\mathrm{PN}_{\mathrm{Mar}}$ was assigned a signature of $8.7 \%$.

\subsection{Particulate nitrogen}

In situ PP is the largest term in the PN budget (23 $400 \pm 1700 \mathrm{Mmol} \mathrm{yr}^{-1}$; Table 5; Fig. 4). Most (94\%, $22000 \mathrm{Mmol} \mathrm{yr}^{-1}$ ) of this $\mathrm{PN}$ is remineralized to DIN within the SoG (Fig. 4). In situ PP effectively removes $720 \mathrm{Mmol} \mathrm{yr}^{-1}$ of $\mathrm{N}$ from the entire SoG as PN buried in the sediment. Most of the $\mathrm{PN}_{\text {Mar }}$ produced by phytoplankton is remineralized within the top $50 \mathrm{~m}$ of the water column, as evidenced by the small flux of sinking particles captured at $50 \mathrm{~m}$ in the sediment traps. Since there are no empirical relationships of $\mathrm{PN}_{\text {Terr }}$ remineralization in the literature, we assumed that loss of this material during its descent to the sediment was negligible. Consequently, the ratio of $\mathrm{PN}_{\mathrm{Mar}}$ to $\mathrm{PN}_{\text {Terr }}$ declines with depth. By $50 \mathrm{~m}$ (sediment trap depth), the $\mathrm{PN}_{\mathrm{Mar}}$ flux in the southern basin is of similar magnitude to that of $\mathrm{PN}_{\mathrm{Terr}}$ (Fig. 4a), and in the southern basin of the strait, the burial in bottom sediments of $\mathrm{PN}_{\mathrm{Terr}}$ exceeds that of $\mathrm{PN}_{\mathrm{Mar}}$ (Fig. 4a). The change in the $\mathrm{PN}_{\mathrm{Mar}}$ to $\mathrm{PN}_{\text {Terr }}$ with water column depth is also supported by the lighter $\delta^{15} \mathrm{~N}$ composition of the sediment relative to the sediment trap samples (see Sect. 3.3).

The southern SoG receives $\sim 2690 \mathrm{Mmol} \mathrm{yr}^{-1}$ of $\mathrm{PN}_{\text {Terr }}$, with most of this flux coming from rivers $\left(2627 \mathrm{Mmol} \mathrm{yr}^{-1}\right.$, Fig. 4a). The northern SoG, in contrast, receives much less $\mathrm{PN}_{\text {Terr }}\left(186 \mathrm{Mmol} \mathrm{yr}^{-1}\right)$ with $59 \%$ of this input $\left(109 \mathrm{Mmol} \mathrm{yr}^{-1}\right)$ due to the advection of particles from the southern strait (Fig. 4a). The difference between the northern and southern basins in the strait reflects that most of the river-borne particles fall out of suspension close to the river mouths.

Atmospheric sources contribute $21.9 \mathrm{Mmol} \mathrm{yr}^{-1}$ of $\mathrm{PN}_{\text {Terr }}$, of which about two-thirds is in the form of $\mathrm{NO}_{3}$ and the rest is $\mathrm{NH}_{4}$ (Table 4a). We have assumed, following Mackas and Harrison (1997), that the $\mathrm{PN}_{\text {Terr }}$ flux from groundwater sources is insignificant $\left(<1 \mathrm{Mmol} \mathrm{yr}^{-1}\right.$, Table 5).

Anthropogenic sources of PN represent $\sim 2 \%$ of the $\mathrm{PN}_{\text {Terr }}$ flux from outside the strait, or $\sim 0.2 \%$ of the total PN flux including marine and terrigenous sources. Municipal wastewater contributes $38 \mathrm{Mmol} \mathrm{yr}^{-1}$ of PN, while aquaculture contributes another $26 \mathrm{Mmol} \mathrm{yr}^{-1}$ (Table 5). The $\mathrm{PN}_{\text {Terr }}$ contribution by pulp mills $\left(5 \mathrm{Mmol} \mathrm{yr}^{-1}\right)$ was estimated based on the ratio of DIN : PN observed by Oakes et al. (2010) for primary treated pulp-mill effluent. Most of the material dumped in the Strait of Georgia at ocean dumping sites is dredged from the Fraser River downstream of our sampling sites, and is consequently already included in the Fraser River $\mathrm{N}$ flux estimate. Some of the $\mathrm{PN}_{\text {Terr }}$ in the dredged material may be remobilized into the water during dumping, but is not likely to be significant and has been neglected in the budget.

The sinks for PN are burial in the sediment and remineralization from the sediment and within the water column. According to the Pace et al. (1987) model, $96 \%$ of the 
$\mathrm{PN}_{\text {Mar }}\left(\sim 22300 \mathrm{Mmol} \mathrm{yr}^{-1}\right)$ produced by phytoplankton in the SoG would be remineralized by the time it descended to the seafloor. Since the small amount of $\mathrm{PN}_{\mathrm{Mar}}$ from aquaculture $\left(26 \mathrm{Mmol} \mathrm{yr}^{-1}\right)$ is also essentially of marine origin, we have assumed that it would remineralize at the same rate. Consequently, we estimate that $\sim 96 \%$ of aquacultureproduced $\mathrm{PN}_{\mathrm{Mar}}\left(25 \mathrm{Mmol} \mathrm{yr}^{-1}\right)$ is remineralized to DIN in the water column (Fig. 4a).

Overall, the fluxes of $\mathrm{PN}$ in SoG sediments are $4191 \mathrm{Mmol} \mathrm{yr}^{-1}$ to the sediment surface, $3165 \mathrm{Mmol} \mathrm{yr}^{-1}$ buried, and $1025 \mathrm{Mmol} \mathrm{yr}^{-1}$ is remineralized (Table 5, Fig. 3). Most (93\%; $2555 \mathrm{Mmol} \mathrm{yr}^{-1}$ ) of the $\mathrm{PN}$ is buried in the southern strait (Fig. 4a). A quarter of the $\mathrm{PN}_{\text {Terr }}$ entering SoG sediments is converted to DIN ( $453 \mathrm{Mmol} \mathrm{yr}^{-1}$ ), with $91 \%$ of the sediment-based remineralization occurring in the south (Fig. 4a). Similarly, a quarter of the $\mathrm{PN}_{\mathrm{Mar}}$ entering SoG sediments is converted to DIN $\left(572 \mathrm{Mmol} \mathrm{yr}^{-1}\right)$, with $81 \%$ occurring in the south (Fig. 4b). There is no quantifiable evidence that $\mathrm{PN}_{\text {Terr }}$ remineralization occurs within the water column, and therefore we have assumed that $\mathrm{PN}_{\mathrm{Terr}}$ is not lost during the settling of particles to the sediment within the SoG.

\subsection{The $\delta^{15} \mathrm{~N}$ composition as a constraint to the $\mathrm{PN}$ budget}

Particulate organic matter reflects the $\delta^{15} \mathrm{~N}$ composition of its source, with terrigenous material having a lower signature than marine-derived material $\delta^{15} \mathrm{~N}$ composition (Peters et al., 1978). The isotopic composition of particles in the SoG aids in identifying processes and sources important to PN fluxes, particularly by providing a way to distinguish between marine and terrestrial contributions. A prior study of sinking particles collected in the southern SoG reported $\delta^{15} \mathrm{~N}$ compositions of 1.5-9\%o (Johannessen et al., 2005). Johannessen et al. (2005) suggested that there was a seasonal effect on the $\delta^{15} \mathrm{~N}$ composition of particles related to the length of the food chain, with lower values observed during phytoplankton blooms (short food chain) than during the rest of the year (long food chain). Here, we have expanded the study area to include the northern Strait of Georgia, where there is a much smaller influence of $\mathrm{PN}_{\text {Terr }}$ from the Fraser River.

In the northern $\mathrm{SoG}$, the remineralization rate of $\mathrm{PN}_{\mathrm{Mar}}$ in the water column (using the Pace et al. (1987) model and a ratio of $\mathrm{C}: \mathrm{N}$ of $6.6: 1)$ suggests that $\mathrm{PP}$ would produce a flux of $\mathrm{PN}_{\mathrm{Mar}}$ at $50 \mathrm{~m}$ of $\sim 1670 \mathrm{Mmol} \mathrm{yr}^{-1}$ based on an area of $3100 \mathrm{~km}^{2}$ (average for burial and surface areas). The measured total PN flux based on the sediment trap at $50 \mathrm{~m}$ depth was determined to be $1776 \mathrm{Mmol} \mathrm{yr}^{-1}$. Given marine and terrigenous end-member $\delta^{15} \mathrm{~N}$ values of $8.7 \%$ and $3.7 \%$, respectively, the measured $\delta^{15} \mathrm{~N}$ composition of $8.2 \%$ in the $50 \mathrm{~m}$ trap particles implies that $92 \%$ of the PN flux at that depth was $\mathrm{PN}_{\mathrm{Mar}}$ with a flux of $1634 \mathrm{Mmol} \mathrm{yr}^{-1}$. The two separate determinations of $\mathrm{PN}_{\mathrm{Mar}}$ flux at $50 \mathrm{~m}$ are encouragingly close, both indicating that the PN flux in the north- ern SoG at $50 \mathrm{~m}$ below sea level is dominated by $\mathrm{PN}_{\mathrm{Mar}}$. It is important to note that the estimated proportion and flux of marine material would vary based on the assigned marine end-member $\delta^{15} \mathrm{~N}$ value of $8.7 \%$ (e.g., the $\mathrm{PN}_{\text {Mar }}$ flux would be greater if the $\delta^{15} \mathrm{~N}$ was lighter). A sensitivity analysis was performed, based on the constraints outlined in Sect. 3.1, to determine the upper and lower limits for this end-member value for both the northern and southern SoG. It was determined that $8.7 \pm 0.3 \%$ o was the most reasonable value for $\delta^{15} \mathrm{~N}$ composition of $\mathrm{PN}_{\mathrm{Mar}}$.

Similarly, in the southern SoG the $\mathrm{PN}_{\mathrm{Mar}}$ flux calculated from the Pace et al. (1987) model was determined to be $\sim 2150 \mathrm{Mmol} \mathrm{yr}^{-1}$ (over $3500 \mathrm{~km}^{2}$ ). The measured total PN flux based on the sediment trap at $50 \mathrm{~m}$ depth was determined to be $3020 \mathrm{Mmol} \mathrm{yr}^{-1}$. Given marine and terrigenous endmember $\delta^{15} \mathrm{~N}$ values of $8.7 \%$ and $1.1 \%$, respectively, the measured $\delta^{15} \mathrm{~N}$ composition of $6.6 \%$ in the $50 \mathrm{~m}$ trap particles implies that $72 \%$ of the $\mathrm{PN}$ at that depth was $\mathrm{PN}_{\mathrm{Mar}}$ with a flux of $2174 \mathrm{Mmol} \mathrm{yr}^{-1}$. Again, the two separate determinations of $\mathrm{PN}_{\mathrm{Mar}}$ flux are very similar and imply that the PN flux in the southern SoG at $50 \mathrm{~m}$ depth is comprised mostly of $\mathrm{PN}_{\mathrm{Mar}}$, but with a much larger terrigenous component than in the north.

The $\delta^{15} \mathrm{~N}$ composition for river particles $\left(\mathrm{PN}_{\text {Terr }}\right)$ was low, relative to $\mathrm{PN}_{\mathrm{Mar}}(-1 \%$ o to $4 \%$ ), which is typical for material of terrigenous origin (Sigman and Casciotti, 2001). For the group of rivers discharging to the northern strait (Campbell, Oyster and Englishman rivers), only Campbell River particles were measured, yielding $\delta^{15} \mathrm{~N}$ values of $3.4 \pm 0.3 \%$ o (Table 3). For the southern strait, the average $\delta^{15} \mathrm{~N}$ composition of PN for the Fraser River, by far the largest contributor, was $1.7 \pm 0.2 \%$, while the other measured rivers (Squamish and Nanaimo) yielded a flux-weighted composition of $-0.5 \pm 1.5 \%$.

The measured $\delta^{15} \mathrm{~N}$ composition of sediment, prior to ultimate burial, in the northern SoG (6.9\%o, Fig. 2, Supplement Table S3) is equivalent to the value calculated from the proportional contributions of its marine and terrigenous sources $(6.9 \%)$. In the southern strait, the measured and calculated $\delta^{15} \mathrm{~N}$ of the sediment are also equivalent (5.3\%o, Fig. 2, Supplement Table S3). The measured $\delta^{15} \mathrm{~N}$ composition of sediment in the SoG after burial is effectively the same as in the surface with a signature of $7.0 \%$ in the north and $5.3 \%$ in the south (Fig. 2, Supplement Table S3).

The transport of $\mathrm{PN}_{\mathrm{Terr}}$ material in the southern $\mathrm{SoG}$ is more complicated than in the north. There are few data available in the southernmost SoG. As described in Sect. 3.1, particle movement in the southern SoG is dynamic and complex (Johannessen et al., 2003). Therefore, the fluxes and movement of PN were estimated using the constraints described in Sect. 3.1 and by ensuring that isotopic mass balance was achieved in both the sediments and SOGS sediment trap. Sources within the SoG were sufficient to account for all of the $\mathrm{PN}_{\mathrm{Terr}}$. However, $64 \%$ of the material that enters the SoG $\left(1724 \mathrm{Mmol} \mathrm{yr}^{-1}\right.$; assigned $\delta^{15} \mathrm{~N}$ of $1.7 \%$ ) is transported 
into Haro Strait. Within Haro Strait, $915 \mathrm{Mmol} \mathrm{yr}^{-1}$ of $\mathrm{PN}_{\text {Terr }}$ is lost and the remaining $809 \mathrm{Mmol} \mathrm{yr}^{-1}$ is mixed with an unknown source of $\mathrm{PN}_{\text {Mar }}$ (assigned $\delta^{15} \mathrm{~N}$ of $8.7 \%$ ) before it re-enters the SoG.

Unfortunately, the influence of this region adjacent to the Haro Strait is the least constrained component of the PN budget. Based on the constraints on the PN budget (Sect. 3.1), the incoming particulate material from Haro Strait $\left(1709 \mathrm{Mmol} \mathrm{yr}^{-1}\right)$ must carry a $\delta^{15} \mathrm{~N}$ composition of $5.4 \%$. Effectively, there is no loss of PN from this budget. Therefore, the $\mathrm{PN}_{\text {Terr }}$ originating from the Fraser River $\left(1.7 \%\right.$ ) must mix with an external source that carries a $\delta^{15} \mathrm{~N}$ composition that is greater than $8.7 \pm 0.3 \%$. To date, the particulate dynamics for this region is not completely understood, and there is a paucity of [PN] and $\delta^{15} \mathrm{~N}$ data along the west coast of North America. For regions adjacent to the SoG, such as Puget Sound (see Fig. 1), there is one study that examines the $\mathrm{C}: \mathrm{N}$ ratio (Walsh et al., 2008) but does not provide [PN], one study (Hedges et al., 1988) that examines the $[\mathrm{PN}]$ of a small coastal bay, and one study (Brandenberger et al., 2011) that has both [PN] and $\delta^{15} \mathrm{~N}$ data from sediment cores sampled at two locations within Puget Sound. Based on the available data, the [PN] within Puget Sound is similar to the concentrations in the southern SoG (Fig. 2) and range from 0.1 to 0.29 wt. \% (Hedges et al., 1988; Brandenberger et al., 2011). Similarly, the $\delta^{15} \mathrm{~N}$ composition of four sediment core samples (two sediment cores per sampling location) collected within the Puget Sound have analogous $\delta^{15} \mathrm{~N}$ compositions to most sediment cores evaluated for the SoG (e.g., GVRD sediment cores 1, 8, 9, 10, 11, 12. 13, 14, 17, 18, 20, 21, 22, see Fig. 2). The $\delta^{15} \mathrm{~N}$ composition of the four sediment cores from Puget Sound ranged from 6.0 to $6.8 \%$ at the sediment-water interface but, subsequently, became isotopically heavier $(6.5-7.2 \%$ ) at depths greater than $50 \mathrm{~cm}$ (Brandenberger et al., 2011). It would be beneficial if another study focussing on the $\delta^{15} \mathrm{~N}$ composition of PN and DIN were to identify what processes are contributing to the mixed $\delta^{15} \mathrm{~N}$ signature coming from Haro Strait.

\subsection{Dissolved inorganic nitrogen (DIN)}

The largest source of DIN to the Strait of Georgia is advective transport into the strait from the Pacific Ocean, driven by estuarine circulation, which accounts for $85 \%$ $\left(29900 \pm 19500 \mathrm{Mmol} \mathrm{yr}^{-1}\right)$ of the DIN flux (Table 5, Fig. 4b). The Fraser River is the next largest source of DIN $\left(1662 \mathrm{Mmol} \mathrm{yr}^{-1}\right)$ and contributes an order of magnitude less $\mathrm{N}$ than advective transport. Our estimate for Fraser River DIN flux $\left(1662 \mathrm{Mmol} \mathrm{yr}^{-1}\right)$ is averaged from data that range from 1184 to $2252 \mathrm{Mmol} \mathrm{yr}^{-1}$, and is therefore equivalent to the $1304 \mathrm{Mmol} \mathrm{yr}^{-1}$ estimated by Mackas and Harrison (1997). Remineralization of $\mathrm{PN}_{\text {Terr }}$ and $\mathrm{PN}_{\mathrm{Mar}}$ in the surface sediment of the strait releases about two-thirds as much DIN as the Fraser River supplies (1025 $\mathrm{Mmol} \mathrm{yr}^{-1}$ ), while the remaining streams flowing into the SoG contribute in aggregate less than one-third of the Fraser River's DIN input, with in-

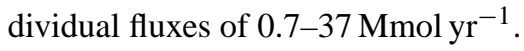

Atmospheric deposition, groundwater and anthropogenic sources represent negligible contributions to the DIN flux (Fig. 4b). The flux of $\mathrm{N}$ into the SoG from the atmosphere is primarily dissolved $\left(82.3-118.5 \mathrm{Mmol} \mathrm{yr}^{-1} ; 76-87 \%\right.$ of the total atmospheric flux; Table 2), about two-thirds of which is $\mathrm{NO}_{3}$ and one-third ammonia. For groundwater flux we have no direct measurements and have, therefore, used the Mackas and Harrison (1997) estimate of 5-15 tonnes day ${ }^{-1}$ (130-391 $\mathrm{Mmol} \mathrm{yr}^{-1}$ ).

Anthropogenic sources (wastewater, aquaculture and pulp mills) together contribute only $\sim 0.7 \%$ of the total DIN flux into the Strait of Georgia (Table 5). Vancouver wastewater from the Iona and Lions Gate treatment facilities contributes $160 \mathrm{Mmol} \mathrm{yr}^{-1}$ of DIN. The Annacis, Lulu and Northwest wastewater treatment facilities discharge into the Fraser River just upstream from our sampling sites, and consequently their inputs are included in the estimated Fraser River $\mathrm{N}$ flux. The DIN flux from pulp mill activities into the SoG was estimated to be $\sim 20 \mathrm{Mmol} \mathrm{yr}^{-1}$, based on the effluent loadings for the facilities at Powell River $\left(5.5 \pm 0.3 \mathrm{Mmol} \mathrm{yr}^{-1}\right)$ and Port Mellon $\left(1.6 \pm 0.2 \mathrm{Mmol} \mathrm{yr}^{-1}\right)$. No data for DIN were available for pulp mill operations in New Westminster, Nanaimo, Squamish or Crofton. Therefore, these locations were assumed to contribute a similar flux to Powell River and Port Mellon (average of the two fluxes: $3.6 \mathrm{Mmol} \mathrm{yr}^{-1}$ ) The DIN flux from all the aquaculture sites in the Strait of Georgia is estimated at $53 \mathrm{Mmol} \mathrm{yr}^{-1}$ (Table 5), based on a maximum total aquaculture production of $22 \times 10^{3}$ metric tonnes of $\mathrm{N}$ over a 2 yr grow-out cycle.

The dominant sink for DIN ( $88 \%$, Fig. 4 b) is advective export of surface water from the SoG to the Pacific Ocean as part of the estuarine circulation $\left(24300 \pm 15500 \mathrm{Mmol} \mathrm{yr}^{-1}\right.$; Fig. 4a). This value agrees with the Mackas and Harrison (1997) estimate of $19410 \mathrm{Mmol} \mathrm{yr}^{-1}$. The uncertainties associated with the advective transports of DIN are large (> 65\%), mainly because of the temporal variation in salinity. Denitrification represents another potential sink for DIN. Given that the SoG is not anoxic, except within a small subsidiary fjord (Saanich Inlet), we assume that denitrification is restricted to basin sediments. Based on sediment denitrification rates for the Washington continental shelf (50-110 $\mu \mathrm{mol} \mathrm{N} \mathrm{m} \mathrm{d}^{-2} \mathrm{~d}^{-1}$; Engstrom et al., 2009), prorated to the area of accreting basin sediments in the SoG, denitrification appears to provide a negligible loss of $\sim 99$ to $217 \mathrm{Mmol} \mathrm{yr}^{-1}$ DIN.

The overall DIN flux into the SoG was estimated to be $\sim 32000( \pm 19500) \mathrm{Mmol} \mathrm{yr}^{-1}$ compared to an overall DIN flux out of $\sim 25600( \pm 15500) \mathrm{Mmol} \mathrm{yr}^{-1}$ (Fig. 4b). The DIN budget shows an excess source of $6400 \mathrm{Mmol} \mathrm{yr}^{-1}$. The uncertainty associated with the exchange of DIN between the strait and the Pacific Ocean is easily large enough to account for the difference. Therefore, we intentionally have 
not forced the sources and sinks to balance for the DIN budget.

\subsection{Dissolved organic nitrogen (DON)}

As in the case of the $\mathrm{N}$ budget by Mackas and Harrison (1997), we have not considered dissolved organic nitrogen (DON) in the dissolved component of the budget for the SoG predominantly because we lack a database to make a confident evaluation of its sources or its potential to support primary productivity. DON data are available for areas adjacent to the SoG, (Saanich Inlet, Stuart Island, Swanson Channel, Juan de Fuca Strait), but no data are available for the SoG (Wong et al., 2002). Recent papers have proposed that DON is a significant contributor to dissolved $\mathrm{N}$ in the ocean (e.g., Duan et al., 2010 (Gulf of Mexico); Letscher et al., 2013 (Arctic Ocean)) and may account for roughly $60 \%$ of the reactive nitrogen in the ocean (Voss and Hietanen, 2013). Based on this evidence, one might assume that exchanges of DON at Haro Strait would be similar to, and perhaps greater than, those of DIN. However, estimated DON fluxes would accrue an even larger uncertainty than the DIN fluxes given the paucity of local data. Likewise, rivers contribute DON in amounts that could be comparable to, or much greater than, DIN (Duan et al., 2010; Letscher et al., 2013; Guo et al., 2004; Dittmar et al., 2001). Even though DON concentrations in aquatic media appear to be significant, it remains very uncertain whether the DON is reactive on the timescales involved in the exchange of water in the SoG (weeks to months). Voss and Hietanen (2013) suggest that the DON may be relatively unreactive in surface waters, but that its breakdown could fuel primary production, especially in oligotrophic regions. The SoG would, accordingly, not be a favorable location for DON to play a large role in supporting primary production. Given these observations, we deem it premature to develop a DON budget at this time. However, the major implications of the DIN budget - that (1) natural supply of DIN is sufficient to support the measured primary production and consequent particle fluxes and (2) natural sources of DIN (ocean and rivers) far exceed anthropogenic sources - would, if anything, be strengthened by the addition of reactive DON to the budget.

\section{Conclusions}

The nitrogen cycle in the Strait of Georgia is driven primarily by the exchange of DIN with the Pacific Ocean through Haro Strait (Fig. 4). A large proportion of the DIN cycles through phytoplankton, entering the particulate cycle temporarily before being remineralized in the water column. Only a small proportion (12\% for entire SoG) of the PN is ultimately buried in the bottom sediment. Since terrigenous material is re-mineralized less efficiently in the water column, the ratio of $\mathrm{PN}_{\text {Terr }}$ to $\mathrm{PN}_{\mathrm{Mar}}$ is higher in accumulating sediment than it is in surface water of the strait, meaning that the sediment record is not an accurate portrayal of PN cycling at the surface.

In contrast to DIN, both $\mathrm{PN}_{\mathrm{Mar}}$ and $\mathrm{PN}_{\text {Terr }}$ owe their origins to external sources (inflow) or processes (e.g., PP) occurring within the strait. The strait appears to be a relatively homogeneous sea with respect to DIN, but the northern and southern basins differ in their sources and fluxes of $\mathrm{PN}_{\mathrm{Terr}}$, with only minimal communication of this component between basins. The far smaller flux of $\mathrm{PN}_{\text {Terr }}$ in the northern SoG means that its contribution to the sediment flux and burial is also smaller both quantitatively and in proportion to $\mathrm{PN}_{\mathrm{Mar}}$.

The ratio of DIN to PN is high in the Fraser River relative to that of the other, smaller rivers that are more typical streams in western Canada (Seitzinger et al., 2002). Seitzinger et al. (2002) state that a high DIN: PN ratio is a sign of anthropogenic activity. This interpretation is consistent with the large urban population in the Fraser River drainage basin (2.3 million; Statistics Canada, 2013) and the use of much of the flat area between Hope and the strait for agriculture compared with the relatively pristine drainage basins of the other rivers.

Within the Strait of Georgia, anthropogenic $\mathrm{N}$ fluxes are negligible for both PN and DIN compared to the natural cycle, which is supported by nutrient-rich water from the Pacific Ocean entrained into the strait through estuarine circulation. It is likely, however, that local effects occur near outfalls or at aquaculture sites, one clear example being at the core 3 site where surface sediments record a change in $\delta^{15} \mathrm{~N}$ values reflecting the installation of a nearby deep-water outfall (Macdonald et al., 2008). If present circumstances favoring light limitation of phytoplankton in the strait were relieved by a change in stratification due to a change in the Fraser River discharge (Morrison et al., 2002; Masson and Pena, 2009), anthropogenic loadings of $\mathrm{N}$ might then contribute to higher productivities. Otherwise, there is little potential for human activities to release sufficient nitrogen to lead to eutrophication.

\section{Supplementary material related to this article is available online at http://www.biogeosciences.net/10/ 7179/2013/bg-10-7179-2013-supplement.pdf.}

Acknowledgements. We thank C. Wright for technical assistance and preliminary data analysis, and D. Spear, M. O'Brien, L. Perreault, T. Juhasz, G. Cooper, K. Scozzafava, L. White, D. Tuele and $M$. Hennekes for assistance at sea and in the field. We thank D. Masson and P. Chandler for collecting nutrient time series in the Strait of Georgia, and G. and W. Richardson, J. Barwell-Clarke, M. Soon and K. Gordon for analyzing nutrient and particulate samples. We thank P. Kimber for preparing figures. We thank Environment Canada, the British Columbia Ministry of Environment, 
Metro Vancouver and the Capital Regional District for providing nitrogen data relevant to this study. We appreciate the assistance of the officers and crew of the CCGS Vector. Funding for the mooring work was provided by Metro Vancouver (Ambient Monitoring Programme) and by the DFO Strait of Georgia Ecosystem Research Initiative. This manuscript greatly benefited from discussions with R. Ickert and from insightful comments provided by two anonymous reviewers.

Edited by: S. Pantoja

\section{References}

Andersson, L. and Rydberg, L.: Trends in nutrient and oxygen conditions within the Kattegat: Effects of local nutrient supply, Estuar. Coast. Shelf Sci., 26, 559-579, 1988.

Baker, E. T., Feely, R. A., Landry, M. R., and Lamb, M.: Temporal variations in the concentration and settling flux of carbon and phytoplankton pigments in a deep fjord-like estuary, Estuar. Coast. Shelf Sci., 21, 859-877, 1985.

Barwell-Clarke, J. and Whitney, F.: Institute of Ocean Sciences nutrient methods and analysis, Department of Fisheries and Oceans, Sidney, British Columbia, 1996.

Bevington, P. R. and Robinson, D. K.: Data reduction and error analysis for the physical sciences, 3rd Ed. McGraw-Hill, New York, 2003.

Boynton, W. R., Garber, J. H., Summers, R., and Kemp, W. M.: Inputs, transformations, and transport of nitrogen and phosphorus in Chesapeake bay and selected tributaries, Estuaries, 18, 285314, 1995.

Brandenberger, J. M., Louchouarn, P., and Crecelius, E. A.: Natural and post-urbanization signatures of hypoxia in two basins of Puget Sound: Historical reconstruction of redox sensitive metals and organic matter inputs, Aquat. Geochem., 17, 645-670, 2011.

British Columbia Ministry of Environment: Environmental Monitoring System Web Reporting, online available at: http://www. env.gov.bc.ca/emswr/, 2013.

Caffrey, J. M., Harrington, N., Solem, I., and Ward, B. B.: Biogeochemical processes in a small California estuary. 2. Nitrification activity, community structure and role in nitrogen budgets, Mar. Ecol.-Prog. Ser., 248, 27-40, 2003.

Calvert, S., Pedersen, T., Naidu, P., and Vonstackelberg, U.: On the organic carbon maximum on the continental slope of the eastern Arabian Sea, J. Mar. Res., 53, 269-296, doi:10.1357/0022240953213232, 1995.

Castro, M. S., Driscoll, C. T., Jordan, T. E., Reay, W. G., and Boynton, W. R.: Sources of nitrogen to estuaries in the United States, Estuaries, 26, 803-814, 2003.

Chapin, T. P., Caffrey, J. M., Jannasch, H. W., Coletti, L. J., Haskins, J. C., and Johnson, K. S.: Nitrate sources and sinks in elkhorn slough, california: Results from long-term continuous in situ nitrate analyzers, Estuaries, 27, 882-894, 2004.

Chen, C. C., Gong, G. C., and Shiah, F. K.: Hypoxia in the East China Sea: One of the largest coastal lowoxygen areas in the world, Mar. Environ. Res., 64, 399-408, doi:10.1016/j.marenvres.2007.01.007, 2007.

Conley, D. J., Bjorck, S., Bonsdorff, E., Carstensen, J., Destouni, G., Gustafsson, B. G., Hietanen, S., Kortekass, M., Kuosa, H., Meier, H. E., Muller-Karulis, B., Nordberg, K., Norkko, A., Nurnberg,
G., Pitkannen, H., Rabalais, N., Rosenberg, R., Savchuk, O., Slomp, C., Voss, M., Wulff, F., and Zillen, L.: Hypoxia-related processes in the Baltic Sea, Environ. Sci. Technol., 43, 34123420, 2009.

Department of Fisheries and Oceans: Current valid marine finfish British Columbia aquaculture licence holders, online available at: http://www.pac.dfo-mpo.gc.ca/aquaculture/ licence-permis/docs/finfish-pisciculture-eng.htm, 2013.

Dittmar, T., Fitzmar, H. P., and Kattner, G.: Origin and biogeochemical cycling of organic nitrogen in the eastern Arctic Ocean as evident from D- and L-amino acids, Geochim. Cosmochim. Ac., 65, 4103-4114, 2001.

Duan, S., Bianchi, T. S., Santschi, P. H., and Amon, R. H. W.: Effects of tributary inputs on nutrient export from the Mississippi and Atchafalaya Rivers to the Gulf of Mexico, Mar. Freshwater Res., 61, 1029-1038, 2010.

Eakins, J. D. and Morrison, R. T.: A new procedure for the determination of lead-210 in lake and marine sediments, Int. J. Appl. Radiat. Is., 29, 531-536, 1978.

Elliott, E. M., Kendall, C., Boyer, E. W., Burns, D. A., Lear, G. G., Golden, H. E., Harlin, K., Bytnerowicz, A., Butler, T. J., and Glatz, R.: Dual nitrate isotopes in dry deposition: Utility for partitioning NOx source contributions to landscape nitrogen deposition, J. Geophys. Res., 114, GB04020, doi:10.1029/2008JG000889, 2009.

Engstrom, P., Penton, C. R., and Devol, A. H.: Anaerobic ammonium oxidation in deep-sea sediments off the Washington margin, Limnol. Oceanogr., 54, 1643-1652, doi:10.4319/lo.2009.54.5.1643, 2009.

Environment Canada: NAtChem, online available at: http://www. on.ec.gc.ca/natchem/Login/Login.aspx, 2013a.

Environment Canada: Water Level and Streamflow Statistics, online available at: http://www.wsc.ec.gc.ca/staflo/index_e.cfm, 2013b.

Freyer, H. D.: Seasonal variation of ${ }^{15} \mathrm{~N} /{ }^{14} \mathrm{~N}$ ratios in atmospheric nitrate species, Tellus B, 43, 30-44, 1991.

Galloway, J. N., Dentener, F. J., Capone, D. G., Boyer, E. W., Howarth, R. W., Seitzinger, S. P., Asner, G. P., Cleveland, C. C., Green, P. A., Holland, E. A., Karl, D. M., Michaels, A. F., Porter, J. H., Townsend, A. R., and Vorosmarty, C. J.: Nitrogen cycles: past, present, and future, Biogeochemistry, 70, 153-226, doi:10.1007/s10533-004-0370-0, 2004.

Garten, C. T.: Stable nitrogen isotope ratios in wet and dry nitrate deposition collected with an artificial tree, Tellus B, 48, 60-64, 1996.

Gordon, D. C., Boudreau, P. R., Mann, K. H., Ong, J. E., Silvert, W. L., Smith, S. V., Wattayakorn, G., Wulff, F., and Yanagi, T.: LOICZ Biogeochemical Modelling Guidelines, LOICZ Reports and Studies 5, Texel., the Netherlands, LOICZ, 96 pp., 1996.

Gower, J., King, S., Statham, S., Fox, R., and Young, E.: The Malaspina Dragon: A newlydiscovered pattern of the early spring bloom in the Strait of Georgia, British Columbia, Canada, Prog. Oceanogr., 115, 181-188, 2013.

Gruber, N. and Galloway, J. N.: An Earth-system perspective of the global nitrogen cycle, Nature, 451, 293-296, doi:10.1038/nature06592, 2008.

Guo, L., Zhang, J.-Z., and Guéguen, C.: Speciation and fluxes of nutrients (N, P, Si) from the upper Yukon River, Global Biogeochem. Cy., 18, GB1038, doi:10.1029/2003GB002152, 2004. 
Hall, P. O. J., Holby, O., Kollberg, S., and Samuelsson, M.-O.: Chemical fluxes and mass balances in a marine fish cage farm. IV. Nitrogen, Mar. Ecol.-Prog. Ser., 89, 91-91, 1992.

Harrison, P. J., Fulton, J. D., Taylor, F. J. R., and Parsons, T. R.: Review of the biological oceanography of the Strait of Georgia - Pelagic environment, Can. J. Fish. Aquat. Sci., 40, 1064-1094, 1983.

Hedges, J. I., Clark, W. A., and Cowie, G. L.: Fluxes and reactivities of organic matter in a coastal marine bay, Limnol. Oceanogr., 33, 1137-1152, 1988.

Hickin, E.: Contemporary Squamish River sediment flux to Howe Sound British Columbia, Can. J. Earth Sci., 26, 1953-1963, doi:10.1139/e89-165, 1989.

Hill, P. R., Conway, K., Lintern, D. G., Meule, S., Picard, K., and Barrie, J. V.: Sedimentary processes and sediment dispersal in the southern Strait of Georgia, BC, Canada, Mar. Environ. Res., 66, S39-S48, doi:10.1016/j.marenvres.2008.09.003, 2008.

JCGM 100: Evaluation of measurement data - Guide to the expression of uncertainty in measurement, 120 pp., 2008.

Johannessen, S. C., Macdonald, R. W., and Paton, D. W.: A sediment and organic carbon budget for the greater Strait of Georgia, Estuar. Coast. Shelf Sci., 56, 845-860, doi:10.1016/s02727714(02)00303-7, 2003.

Johannessen, S. C., O'Brien, M. C., Denman, K. L., and Macdonald, R. W.: Seasonal and spatial variations in the source and transport of sinking particles in the Strait of Georgia, British Columbia, Canada, Mar. Geol., 216, 59-77, doi:10.1016/j.margeo.2005.01.004, 2005.

Johannessen, S. C., Potentier, G., Wright, C. A., Masson, D., and Macdonald, R. W.: Water column organic carbon in a Pacific marginal sea (Strait of Georgia, Canada), Mar. Environ. Res., 66, S49-S61, doi:10.1016/j.marenvres.2008.07.008, 2008.

Justic, D., Legovic, T., and Rottini-Sandrini, L.: Trends in oxygen content 1911-1984 and occurrence of benthic mortality in the northern Adriatic Sea, Estuar. Coast. Shelf Sci., 25, 435-445, 1987.

Kaldy, J. E.: Carbon, nitrogen, phosphorus and heavy metal budgets: How large is the eelgrass (zostera marina 1.) sink in a temperate estuary?, Mar. Pollut. Bull., 52, 342-353, 2006.

LeBlond, P. H.: The Strait of Georgia: Functional anatomy of a coastal sea, Can. J. Fish. Aquat. Sci., 40, 1033-1063, 1983.

Letscher, R. T., Hansell, D. A., Kadko, D., and Bates, N. R.: Dissolved organic nitrogen dynamics in the Arctic Ocean, Mar. Chem., 148, 1-9, 2013.

Macdonald, R. W., Johannessen, S. C., Gobeil, C., Wright, C., Burd, B., Van Roodselaar, A., and Pedersen, T. F.: Sediment redox tracers in Strait of Georgia sediments - Can they inform us of the loadings of organic carbon from municipal wastewater, Mar. Environ. Res., 66, S87-S100, 2008.

Mackas, D. L. and Harrison, P. J.: Nitrogenous nutrient sources and sinks in the Juan de Fuca Strait/Strait of Georgia/Puget Sound estuarine system: Assessing the potential for eutrophication, Estuar. Coast. Shelf Sci., 44, 1-21, doi:10.1006/ecss.1996.0110, 1997.

Masson, D.: Seasonal water mass analysis for the Straits of Juan de Fuca and Georgia, Atmos.-Ocean, 44, 1-15, doi:10.3137/ao.440101, 2006.
Masson, D. and Pena, A.: Chlorophyll distribution in a temperate estuary: The Strait of Georgia and Juan de Fuca Strait, Estuar. Coast. Shelf Sci., 82, 19-28, 2009.

Mathieu, G. C., Biscaype, P. E., Lupton, R. A., and Hammond, D. E.: System for measurement of Rn-222 at low levels in natural waters, Health Phys., 55, 989-992, 1988.

Morrison, J., Quick, M. C., and Foreman, M. G. G.: Climate change in the Fraser River watershed: flow and temperature projections, J. Hydrol., 263, 230-244, 2002.

Nixon, S. W., Granger, S. L., and Nowicki, B. L.: An assessment of the annual mass balance of carbon nitrogen and phosphorus in Narragansett Bay, Biogeochemistry, 31, 15-61, 1995.

Oakes, J. M., Eyre, B. D., Ross, D. J., and Turner, S. D.: Stable isotopes trace estuarine transformations of carbon and nitrogen from primary- and secondary-treated paper and pulp mill effluent, Envir. Sci. Tech., 44, 7411-7417, 2010.

Pace, M. L., Knauer, G. A., Karl, D. M., and Martin, J. H.: Primary production, new production and vertical flux in the eastern Pacific Ocean, Nature, 325, 803-804, 1987.

Parsons, T. R., Albright, L. J., and Parslow, J.: Is the Strait of Georgia becoming more eutrophic - Comment, Can. J. Fish. Aquat. Sci., 37, 1043-1047, 1980.

Parsons, T. R., LeBrasseur, R. J., and Barraclough, W. E.: Levels of production in pelagic environment of Strait of Georgia, British Columbia - A review, J. Fish. Res. Board Can., 27, 1251-1264, 1970.

Parsons, T. R., Stronach, J., Borstad, G. A., Louttit, G., and Perry, R. I.: Biological fronts in the Strait of Georgia, British Columbia, and their relation to the recent measurements of primary productivity, Mar. Ecol.-Prog. Ser., 6, 237-242, doi:10.3354/meps006237, 1981.

Pawlowicz, R., Riche, O., and Halverson, M.: The circulation and residence time of the Strait of Georgia using a simple mixing-box approach, Atmos.-Ocean, 45, 173-193, 2007.

Peters, K. E., Sweeney, R. E., and Kaplan, I. R.: Correlation of carbon and nitrogen stable isotope ratios in sedimentary organic matter, Limnol. Oceanogr., 23, 598-604, 1978.

Rabalais, N. N.: Nitrogen in aquatic ecosystems, Ambio, 31, 102-112, doi:10.1639/0044-7447(2002)031[0102:niae]2.0.co;2, 2002.

Redfield, A. C., Ketchum, B. H., and Richards, F. A.: The influence of organisms on the composition of seawater, in The Sea, 2, 2677, Wiley, Interscience, New York, 1963.

Sanchez-Carrillo, S., Sanchez-Andres, R., Alatorre, L. C., Angeler, D. G., Alvarez-Cobelas, M., and Arreola-Lizarraga, J. A.: Nutrient fluxes in a semi-arid microtidal mangrove wetland in the gulf of California, Estuar. Coast. Shelf. Sci., 82, 654-662, 2009.

Schaefer, S. C. and Alber, M.: Temperature controls a latitudinal gradient in the proportion of watershed nitrogen exported to coastal systems, Biogeochemistry, 85, 333-346, 2007.

Seitzinger, S. P., Kroeze, C., Bouwman, A. F., Caraco, N., Dentener, F., and Styles, R. V.: Global patterns of dissolved inorganic and particulate nitrogen inputs to coastal systems: Recent conditions and future projections, Estuaries, 25, 640-655, doi:10.1007/bf02804897, 2002.

Sigman, D. M. and Casciotti, K. L.: Nitrogen isotopes in the ocean, in: Encyclopedia of Ocean Science, edited by: Steele, J. H., Turekian, K. K., and Thorpe, S. A., 1884-1894, Academic Press, London, 2001. 
Smith, S. V. and Hollibaugh, J. T.: Annual cycle and interannual variability of ecosystem metabolism in a temperature climate embayment, Ecol. Monogr., 67, 509-533, 1997.

Smith, S. V. and Hollibaugh, J. T.: Water, salt, and nutrient exchanges in san francisco bay, Limnol. Oceanogr., 51, 504-517, 2006.

Statistics Canada: GeoSearch. 2011 Census, online available at: http://geodepot.statcan. gc.ca/GeoSearch2011-GeoRecherche2011/

GeoSearch2011-GeoRecherche2011.jsp?lang=E\&otherLang=F, 2013.

Stockner, J. G., Cliff, D. D., and Shortreed, K. R. S.: Phytoplankton ecology of the Strait of Georgia, British Columbia, J. Fish. Res. Board Can., 36, 657-666, 1979.

Sutherland, T. F., Amos, C. L., Ridley, C., Droppo, I. G., and Petersen, S. A.: The settling behaviour and benthic transport of fish feed pellets under steady flows, Coastal and Estuarine Research Federation, 29, 810-819, 2006.

Thomas, C. A. and Bendell-Young, L. I.: The significance of diagenesis versus riverine input in contributing to the sediment geochemical matrix of iron and manganese in an intertidal region, Estuar. Coast. Shelf S., 48, 635-647, doi:10.1006/ecss.1998.0473, 1999.
Thomson, R. E.: Oceanography of the British Columbia coast, Can. Spec. Publ. Fish. Aquat. Sci., 56, 291 pp., 1981.

Turner, R. E. and Rabalais, N. N.: Coastal eutrophication near the Mississippi river delta, Nature, 368, 619-621, 1994.

Voss, M. and Hietanen, S.: The depths of nitrogen cycling, Nature, 493, 616-618, 2013.

Walsh, E. M., Ingalls, A. E., and Keil, R. G.: Sources and transport of terrestrial organic matter in Vancouver Island fjords and the Vancouver-Washighton Margin: A multiproxy approach using $\delta^{13} \mathrm{C}_{\text {org }}$, lignin phenols, and the ether lipid BIT index, Limnol. Oceanogr., 83, 1054-1063, 2008.

Wong, C. S., Yu, Z., Waser, N. A. D., Whitney, F. A., and Johnson, W. K.: Seasonal changes in the distribution of dissolved organic nitrogen in coastal and open-ocean waters in the North East Pacific: sources and sinks, Deep-Sea Res. Pt. II, 49, 5759-5773, 2002 . 